SR 115

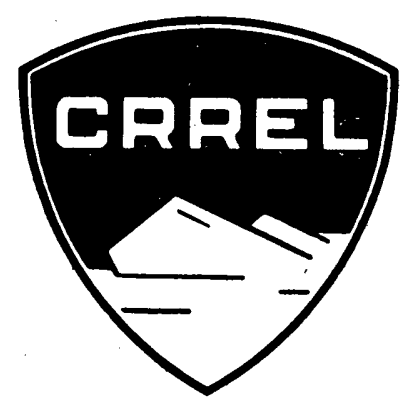

Special Report 115

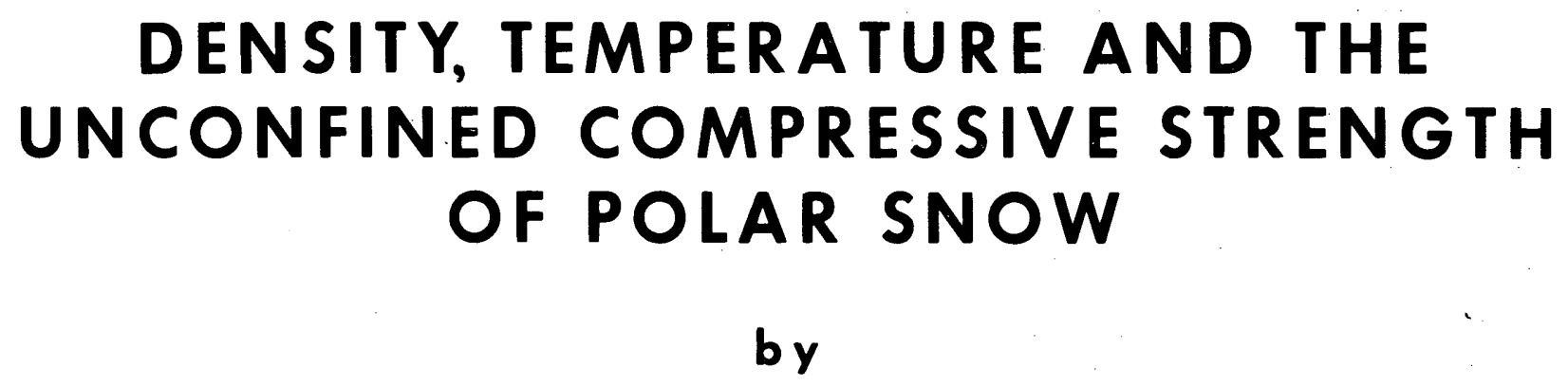

Austin Kovacs

JULY 1967

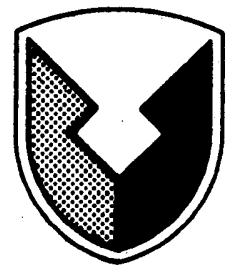




\section{Erratum - USA CRREL Special Report 115}

Page 13: The units for slope, intercept and standard error of estimate in Table III should read $\mathrm{kg} \mathrm{cm} / \mathrm{g}, \mathrm{kg} / \mathrm{cm}^{2}$ and $\mathrm{kg} / \mathrm{cm}^{2}$ respectively for Ramseier's data and dynes $\mathrm{cm} / \mathrm{g}$, dynes $/ \mathrm{cm}^{2}$ and dynes $/ \mathrm{cm}^{2}$ respectively for J.L.Smith's data. 


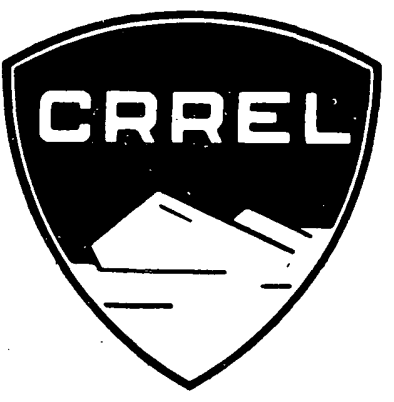

Special Report 115

\section{DENSITY, TEMPERATURE AND THE UNCONFINED COMPRESSIVE STRENGTH OF POLAR SNOW} by

Austin Kovacs

JULY 1967

\section{U.S. ARMY MATERIEL COMMAND \\ COLD REGIONS RESEARCH \& ENGINEERING LABORATORY HANOVER, NEW HAMPSHIRE}

DA Task IVO25001A13001

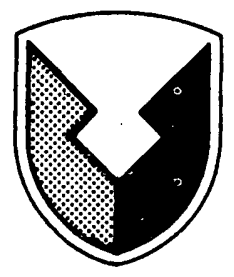




\section{PREFACE}

This study was performed by Mr. Austin Kovacs under U.S. Army Cold Regions Research and Engineering Laboratory (USA CRREL) task, Experimental Engineering in Snow, Ice and Frozen Ground.

Information reported herein was initiated by USA CRREL in the Construction Engineering Branch, Mr. Edward F. Lobacz, Chief, of the Experimental Engineering Division, Mr. Kenneth A. Linell, Chief.

The author wishes to acknowledge the time and advice contributed by Messrs. Lawrence Colyer, Anthony J. Gow, Frank Michitti, and Steven J. Mock of USA CRREL during the preparation of this report. Technical review was performed by Mr. René O. Ramseier.

USA CRREL is an Army Materiel Command laboratory. 
Preface-1.

Summary -.-.--

Introduction

Existing methods for determining the unconfined compressive

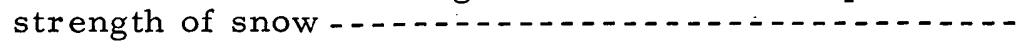

Comparison of the five unconfined compressive strength equations for snow at $-10 \mathrm{C}$

Temperature correction factors - 11

Unconfined compressive strength of polar snow vs depth-density and temperature

Discussion -

Conclusions,

Literature cited -... 18

Appendix A. Test data

Appendix B. Statistical data for polynomial expressions fitting J. L. Smith's dynamic Young's and shear modulus data

Appendix C. Relationship between the unconfined compressive strength of polar snow and its dynamic Young 's and

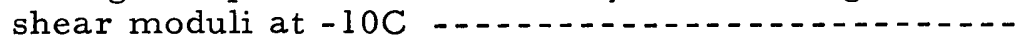

\section{ILLUSTRATIONS}

Figure

1. Unconfined compressive strength vs temperature for clear

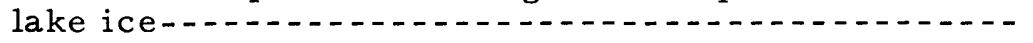

2. Existing unconfined compressive strength vs density relationships for polar snow at $-10 \mathrm{C}$

3. Linear relationships of unconfined compressive strength vs density for data of Butkovich and J. L. Smith above and below the transition density of $0.50 \mathrm{~g} / \mathrm{cm}^{3}$

4. Linear unconfined compressive strength vs density relationships for the combined Butkovich and J. L. Smith data above and below the transition density of 0.50 $\mathrm{g} / \mathrm{cm}^{3}$ in relation to the polynomial relationship for

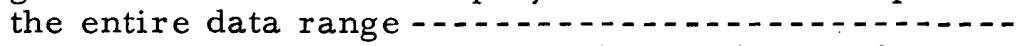

5. Curve trend comparison between the eq 11 unconfined compressive strength relationship and J. L. Smith's dynamic Young's modulus vs density relationship-.--

6. Comparison of the unconfined compressive strength vs density relationship of eq 11 with earlier relationships

7. Comparison between the Ballard-Feldt and eq 11 unconfined compressive strength vs density relationships -

8. Relative unconfined compressive strength vs temperature

9. Intercept density relationship between the extended straight-line portions of different tests-1..-...-

10. Relationship between values obtained from the different unconfined compressive strength equations when they are used to determine strengths from depth-density and temperature profiles -.............................

11. Comparison between the values obtained from eq 9, temperature-corrected after Bender (eq 12), and from eq 14 when they are used to determine the unconfined compressive strength of polar snow from depth-density and temperature profiles 
TABLES

Table

I. Statistical data related to curves in Figure 3

II. Statistical data related to polynomial curve in Figure 4--- 8

III. Statistical data related to curves in Figure 9.... 13

IV. Unconfined compressive strength relationships ........ 


\section{SUMMARY}

The relationships between several empirical and theoretical methods for determining the unconfined compressive strength of polar sriow from depth-density and temperature profiles are discussed and graphically compared. Two unconfined compressive strength equations are proposed for snow at $-10 \mathrm{C}$ :

$$
\sigma_{c}=1719(\gamma-0.422)
$$

and:

$$
\sigma_{c}=968-6646 \gamma+13520 \gamma^{2}-7235 \gamma^{3} .
$$

These equations apply to snow densities from 0.50 to $0.72 \mathrm{~g} / \mathrm{cm}^{3}$ and 0.36 to $0.72 \mathrm{~g} / \mathrm{cm}^{3}$, respectively. 


\title{
DENSITY, TEMPERATURE AND THE UNCONFINED COMPRESSIVE STRENGTH OF POLAR SNOW
}

by

\author{
Austin Kovacs
}

\section{INTRODU்CTION}

A number of methods have been presented for determining the unconfined compressive strength of polar snow when density and temperature are known. Of particular interest to those concerned with snow's resistance to pile driving are the methods devised by Ballard and Feldt (1965), Ballard and McGaw (1965), Butkovich (1956), Mellor and J.H. Smith (1966) and J. L. Smith (1965). The unconfined compressive strengths obtained by these methods, however, were found to deviate considerably from one another with both density and temperature.

This report covers a study made to determine why the anomalies exist. Where possible, inconsistencies in test procedures and data analysis used to develop existing unconfined compressive. strength formulas are pointed out. Two equations for determining the unconfined compressive strength of snow are proposed. The formulas take into consideration the decided changes in slope of the Young's and shear modulus curves at a density of $0.5 \mathrm{~g} / \mathrm{cm}^{3}$ for Greenland snow. The slope changes signify that at this density a structural and, therefore, a strength change occur. Analysis of existing test data indicates this reasoning to be valid.

\section{EXISTING METHODS FOR DETERMINING THE UNCONFINED COMPRESSIVE STRENGTH OF SNOW}

From a comparison of horizontal snow samples tested at Site II, Greenland, Butkovich (1956) developed an empirical relationship between unconfined compressive strength and density for snow at - loC:

$$
\sigma_{c}=1418(\gamma-0.39)
$$

where:

$$
\begin{aligned}
& \sigma_{c}=\text { unconfined compressive strength, psi } \\
& \gamma=\text { snow density, } \mathrm{g} / \mathrm{cm}^{3}:
\end{aligned}
$$

Butkovich broke his samples with a Carver hand-actuated hydraulic press. This type of press is not considered ideal for unconfined compression testing because it produces undesirable pulsed loading and head speeds with each pump of the hydraulic jack. The speed at which the press was operated is not known but the average load rate was reported to be 7.5 psi $\left(0.5 \mathrm{~kg} / \mathrm{cm}^{2}\right)$ per second. Jellinek (1957) has found that in testing the tensile strength of ice at. $-4.5 \mathrm{C}$ the magnitude of the results is no longer dependent on the loading rate above $0.5 \mathrm{~kg} / \mathrm{cm}^{2}$ per second. It cannot be assumed, however, that the same is true for unconfined compression tests performed on snow at $-10 \mathrm{C}$. Butkovich (1958) and Mellor and J.H. Smith (1966) have shown that the unconfined compressive strength of snow is dependent upon temperature and load rate. The load rate required to mask the plastic effects of deformation is in turn dependent upon the temperature and density of the snow. Therefore, it cannot be assumed that the strain rate for these tests was sufficient to subject the samples to brittle failure over the entire density range. 
Butkovich's samples consisted of cores 3 in. $(7.62 \mathrm{~cm})$ in diameter with a length-to-diameter ratio of 2.2 to 1 . This ratio was perhaps too low to eliminate the effect of end constraint (Butkovich, 1958).

At Camp Century, Greenland, J. L. Smith (1965) found a relationship similar to Butkovich's for vertical snow samples at -10C:

$$
\sigma_{c}=1542(\gamma-0.40) \text {. }
$$

A constant-velocity motorized press having a head speed of 1 in. $(2.54 \mathrm{~cm}$ ) per minute was used in these tests. The samples were uniformly trimmed to $2.00 \mathrm{in.}(5.08 \mathrm{~cm})$ in diameter with a special shaver and had a length-todiameter ratio of 2.5 to 1 .

Ballard and McGaw (1965) presented a theory that attempted to explain snow failure or unconfined compressive strength at any temperature in terms of the crushing strength of snow ice* and the porosity of snow when $\gamma>0.46$ $\mathrm{g} / \mathrm{cm}^{3}$ :

$$
\sigma_{f}=\sigma_{i}\left(1-\frac{n}{n_{L}}\right)
$$

where:

$$
\begin{aligned}
\sigma_{\mathrm{f}}= & \text { failure strength, psi } \\
\sigma_{\mathrm{i}}= & \begin{array}{l}
\text { ultimate strength of fine-grained, randomly oriented } \\
\text { polycrystalline ice, psi }
\end{array} \\
\mathrm{n}= & \text { volumetric porosity of the given snow density } \\
\mathrm{n}_{\mathrm{L}}= & \text { limiting porosity, i. e. volumetric porosity at which } \\
& \sigma_{\mathrm{f}} \text { is zero (extrapolated). }
\end{aligned}
$$

Ballard and Feldt (1965) calculated the effective porosity $\left(n_{f}\right) \dagger$ as a function of porosity over the entire porosity range and developed the following equation:

$$
\sigma_{f}=\sigma_{i} e^{-2(n / 1-n)}
$$

Mellor and J.H. Smith (1966) presented an unconfined compressive strength equation for snow based upon the crushing strength/of ice** and the void ratio:

$$
\sigma_{c}=\sigma_{i} e^{-b r^{2}}
$$

*Snow ice in this report refers to consolidated snow with zero permeability.

$\dagger$ The effective porosity $\left(n_{f}\right)$ is defined by Ballard and Feldt as the porosity of the snow along the failure surface. Their geometrical considerations show $\mathrm{n}_{\mathrm{f}}$ to be approximately twice $\mathrm{n}$.

***Mellor and J.H. Smith suggest using the strength of clear lake ice for $\sigma_{i}$ as they believe this would represent an optimum value for snow ice at a density of $0.917 \mathrm{~g} / \mathrm{cm}^{3}$. 
where:

$$
\begin{aligned}
& \mathrm{b}=\mathrm{a} \text { dimensionless constant } \\
& \mathrm{r}=\text { void ratio of the snow. }
\end{aligned}
$$

To develop this equation Mellor and J.H. Smith tested samples prepared from snow ground through a $\mathrm{l}-\mathrm{mm}$ sieve. The snow was compacted in tubes (5. $72 \mathrm{~cm}$ diam, $18.9 \mathrm{~cm}$ long) and allowed to sinter for approximately 3 weeks at $-10 \mathrm{C}$. At the end of this period the samples were exposed to the test temperature $(0$ to $-50 \mathrm{C})$ for 6 hours before being broken. The samples were crushed under a motorized press with a head speed of 3.64 in. 19.25 $\mathrm{cm})$ or 5.77 ini. $(14.65 \mathrm{~cm})$ per minute.

\section{COMPARISON OF THE FIVE UNCONFINED COMPRESSIVE STRENGTH EQUATIONS FOR SNOW AT -10C}

To use the theoretical expression developed by Ballard and McGaw (eq 3) the limiting porosity and ultimate strength of snow ice have to be determined. To apply this equation to Camp Century snow the necessary values are obtained from the experimental values of J. L. Smith. From eq 2, $\sigma_{c}=0$ at a density of $0.40 \mathrm{~g} / \mathrm{cm}^{3}$ and $\mathrm{n}_{\mathrm{L}}$ becomes $1-1.09 \mathrm{\gamma}=0.564$. Assuming a density of $0.917 \mathrm{~g} / \mathrm{cm}^{3}$ for snow ice and extrapolating $\sigma_{c}$ to $\sigma_{i}$, a value of $800 \mathrm{psi}$ $\left(56.1 \mathrm{~kg} / \mathrm{cm}^{2}\right)$ is obtained from eq 2 .

Since the Ballard and McGaw (1965) equation is a straight line, the unconfined compressive strength when plotted against porosity for each test temperature results in a family of straight lines which pass through zero strength at the limiting porosity and maximum strength at zero porosity. It should, therefore, be obvious that using 800 psi for $\sigma_{i}$ along with 0.564 for $\mathrm{n}_{\mathrm{L}}$ in eq 3 gives strengths directly obtainable from the simple J. L. Smith equation. Equation 3 is merely a method for expressing any linear unconfined compressive strength vs density relationship in terms of porosity.

It should be pointed out that some investigators have used the temperature dependence of clear lake ice (Fig. 1) to obtain $\sigma_{i}$ (Abele et al., 1966; Ramseier, 1966). There is no justification for doing this unless it is desired to obtain $\sigma_{c}$ values which are low and, therefore, provide a factor of safety for engineering purposes.

The exponential parameters of eq 5 can be changed to coincide with those of eq 4. The constant $\mathrm{b}$ in eq 5 has been tentatively interpreted as an index of grain structure. Using J.L. Smith's test results and eq 5, Mellor found $b$ to be 1.8 for Camp Century snow. With the void ratio being directly related to porosity $(r=n / l-n)$ and the constant $b$ known, eq 5 can be expressed as follows:

$$
\sigma_{c}=\sigma_{i} e^{-1 \cdot 8(n / 1-n)^{2}} \text {. }
$$

A graphic comparison relating unconfined compressive strength vs density as derived from all the equations is presented in Figure 2 . To show the effect of using $\sigma_{i}$ for lake ice $\left(700 \mathrm{psi}\right.$ or $49.2 \mathrm{~kg} / \mathrm{cm}^{2}$ at $-10 \mathrm{C}$ ) upon the unconfined compressive strength vs density relationship, this value is used in eq 3 and 4 for the related curves in Figure 2. Equation 4 is also graphically shown when an ultimate strength of $800 \mathrm{psi}\left(56.1 \mathrm{~kg} / \mathrm{cm}^{3}\right)$ is used for $\sigma_{i}$ as extrapolated from eq 2 . 


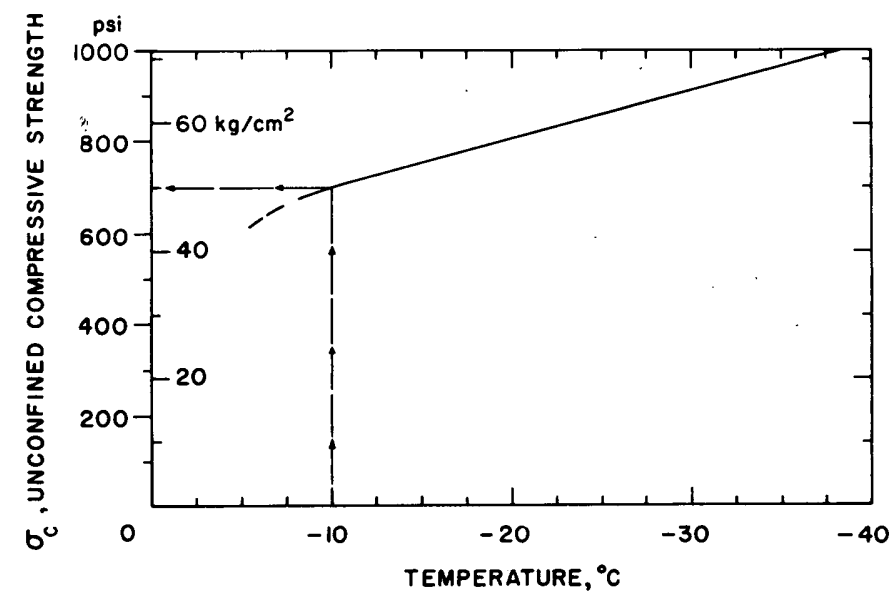

Figure 1. Unconfined compressive strength vs temperature for clear lake ice (from Butkovich, 1964).

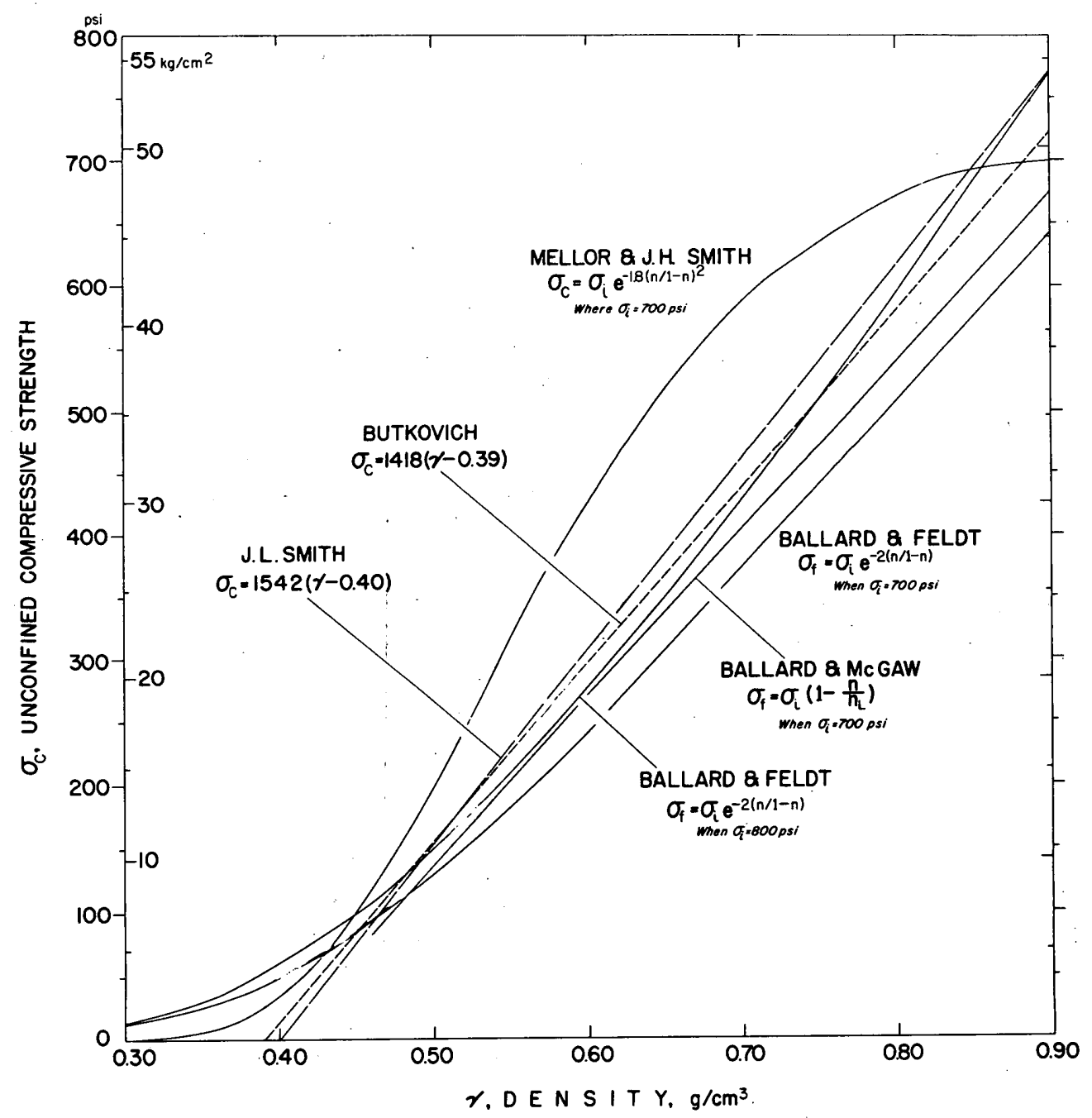

Figure 2. Comparison of existing unconfined compressive strength vs density relationships for polar snow at $-10 \mathrm{C}$. 
From:an inspection of Figure 2, it is apparent that considerable dis crepancy exists.between the strengths obtained from the different unconfined compressive'strength vs density relationships as presently used. It is believed that the development of the Mellor-J.H. Smith equation could have been adversely affected by the snows tested. Although sintered particle size might have been comparable to that of polar snow of similar density, the samples might not have adequately represented the sintered structure or strength of natural snows of comparable density. Mellor recently has suggested that the large divergence from the-other unconfined compressive strength values was due to the temperature and strain rate at which his samples were broken. The strain rate was apparently below that necessary to cause brittle failure in the higher temperature snows. If this did occur, the results would be influenced by creep effects and would be more applicable to snow subjected to creep failure than to the structural collapse of snow associated with brittle failure.

The difference in $\sigma_{f}$ between the Ballard-McGaw and Ballard-Feldt curves is related to the considerations upon which their equations were based and the different values of $\sigma_{i}$ used.

The slight disagreement between the Butkovich and J.L. Smith rectilinear strength vs density values may have resulted from the different loading characteristics of the test apparatuses and the different length to diameter ratios of the test samples. Although the relationships of Butkovich and Smith are useful for a number of purposes, they do not adequately relate unconfined compressive strength to snow density. This is especially true for snow densities in the pronounced transition range between low-density openstructured snow of about $0.30 \mathrm{~g} / \mathrm{cm}^{3}$ and high-density snows of about 0.52 $\mathrm{g} / \mathrm{cm}^{3}$ where a sintered transition (stable bond structure) is established within thermally stable in-situ snows (Ramseier, 1963; Gow, 1966).

Although previously mentioned test inconsistencies are believed to have affected the test results, the linearization of the unconfined compressive strength vs snow density relationship into a single equation definitely resulted in less agreement in the correlation of unconfined compressive strength and density. To show this, the Butkovich and J. L. Smith data (Appendix A, Tables AI and AII) were replotted (Fig. 3). Unconfined compressive strengths obtained at temperatures other than $-10 \mathrm{C}$ were not included to eliminate any strength error associated with the use of a temperature correction factor.

An inspection of the replotted data showed a decided change in unconfined compressive strength vs density at a density of about $0.50 \mathrm{~g} / \mathrm{cm}^{3}$. At a similar density, changes in the Young's and shear modulus curves occur (Nakaya, 1959; J.'L. Smith, 1965). This indicates a structural change associated with the transition between low-density open-structured snow and closely packed high-density snow in which a sintered transition has been established. Another indication of a structural change existing in in-situ snow at a density of $0.50 \mathrm{~g} / \mathrm{cm}^{3}$ is the bend in the $P$-wave velocity curve near this density depth at Camp Century (Clark, 1966). Because this density appears to represent an area where significant changes in both physical and mechanical measurements occur, : it is tentatively referred to as the "transition density."

Using the foregoing observations as a guide, an arithmetic least squares analysis of the Butkovich and J. L. Smith data was made between the transition density and therhighest test density of $0.72 \mathrm{~g} / \mathrm{cm}^{3}$. An analysis of the combined data in this density range was also made. Because of insufficient 


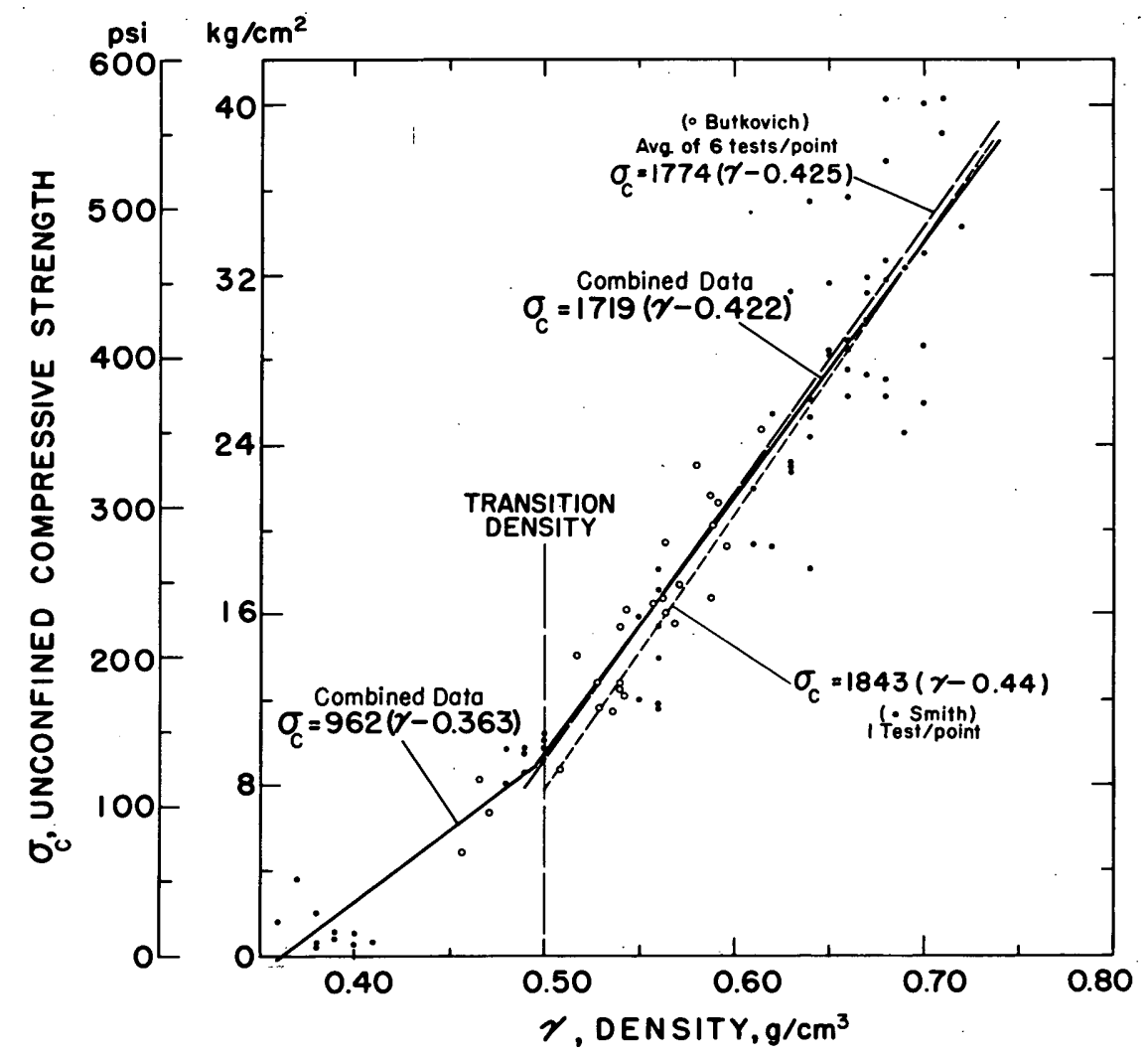

Figure 3. Linear relationships of unconfined compressive strength vs density for data of Butkovich and J.L. Smith above and below the transition density of $0.50 \mathrm{~g} / \mathrm{cm}^{3}$. Snow temperature $-10 \mathrm{C}$.

Table I. Statistical data related to curves in Figure 3.

\begin{tabular}{|c|c|c|c|c|}
\hline Symbols & $\begin{array}{c}\text { Butkovich } \\
y=0.50 \text { to } 0.62 \mathrm{~g} / \mathrm{cm}^{3}\end{array}$ & $\begin{aligned} \text { J. I. Smith } \\
Y=0.50 \text { to } 0.72 \mathrm{~g} / \mathrm{cm}^{3}\end{aligned}$ & $\begin{array}{r}\text { J. L. Smith a } \\
y=0.50 \text { to } 0.72 \mathrm{~g} / \mathrm{cm}^{3}\end{array}$ & $\begin{array}{l}\text { nd Butkovich } \\
y=0.36 \text { to } 0.49 \mathrm{~g} / \mathrm{cm}^{3}\end{array}$ \\
\hline Slope $\mathrm{m}, \mathrm{psi} /\left(\mathrm{g} / \mathrm{cm}^{3}\right)$ & 1. $774 \times 10^{3}$ & $1.843 \times 10^{3}$ & $1.719 \times 10^{3}$ & $9.625 \times 10^{2}$ \\
\hline Intercept a, psi & $-7.534 \times 10^{2}$ & $-8.108 \times 10^{2}$ & $-7.251 \times 10$ & $3.494 \times 10^{2}$ \\
\hline Std error of est $S_{y_{e}}$ psi & $2.418 \times 10$ & $5.927 \times 10$ & $3.719 \times 10$ & $1.939 \times 10$ \\
\hline Simple corr coef $R$ & 0.912 & 0.874 & 0.925 & 0.907 \\
\hline
\end{tabular}


test data between the transition density and the lowest test density 0.36 $\mathrm{g} / \mathrm{cm}^{3}$ ) to permit the establishment of individual unconfined compressive strength vs density relationships, only a combined data analysis was made. For snow in the $0.50 \mathrm{~g} / \mathrm{cm}^{3}$ to $0.72 \mathrm{~g} / \mathrm{cm}^{3}$ density range, the analyses gave the following unconfined compressive strength relationships:

For Butkovich's data (138 tests):

$$
\sigma_{c}=1774(\gamma-0.425) \text {. }
$$

For J. L. Smith's data (54 tests):

$$
\sigma_{c}=1843(\gamma-0.440) \text {. }
$$

For the combined data (192 tests):

$$
\sigma_{c}=1719(\gamma-0.422) \text {. }
$$

The 35 tests below the density of $0.50 \mathrm{~g} / \mathrm{cm}^{3}$ rendered an unconfined compressive strength vs density relationship of:

$$
\sigma_{c}=962(\gamma-0.360) \text {. }
$$

Immediately apparent from Figure 3 is the reasonably close agreement between the rectilinear curves passing through the combined J. L. Smith and Butkovich data.

J. L. Smith (1965) has shown that plotting the Young's and shear moduli vs density results in a rectilinear curve above the transition density of $0.50 \mathrm{~g} / \mathrm{cm}^{3}$. Below this density the curves bow toward the left, intercepting the $\mathrm{x}$-axis at some density below $0.30 \mathrm{~g} / \mathrm{cm}^{3}$. To determine whether or not the Butkovich-J. L. Smith test results would fit a comparable trend with good statistical data - curve correlation, a computer evaluation (Mock, 1966) was made. The combined data were fitted with arithmetic, exponential, power and 2nd-5th degree polynomial regression equations. Statistically, the following $3 \mathrm{rd}$ degree polynomial regression curve fitted the data best:

$$
\sigma_{c}=988-6646 \gamma+13520 \gamma^{2}-7235 \gamma^{3} \text {. }
$$

This equation is only valid for natural snow between the densities of 0.36 and $0.72 \mathrm{~g} / \mathrm{cm}^{3}$. Above or below this range the formula gives erroneous unconfined compressive strengths.

Equation 11, along with the previously presented linear expressions for the combined data above and below the transition density, is shown graphically in Figure 4. Here it is seen that the polynomial not only becomes quasi-linear above the density of $0.52 \mathrm{~g} / \mathrm{cm}^{3}$ but follows the linear relationships for the combined data above the transition density. 
DENSITY, TEMPERATURE AND STRENGTH OF POLAR SNOW

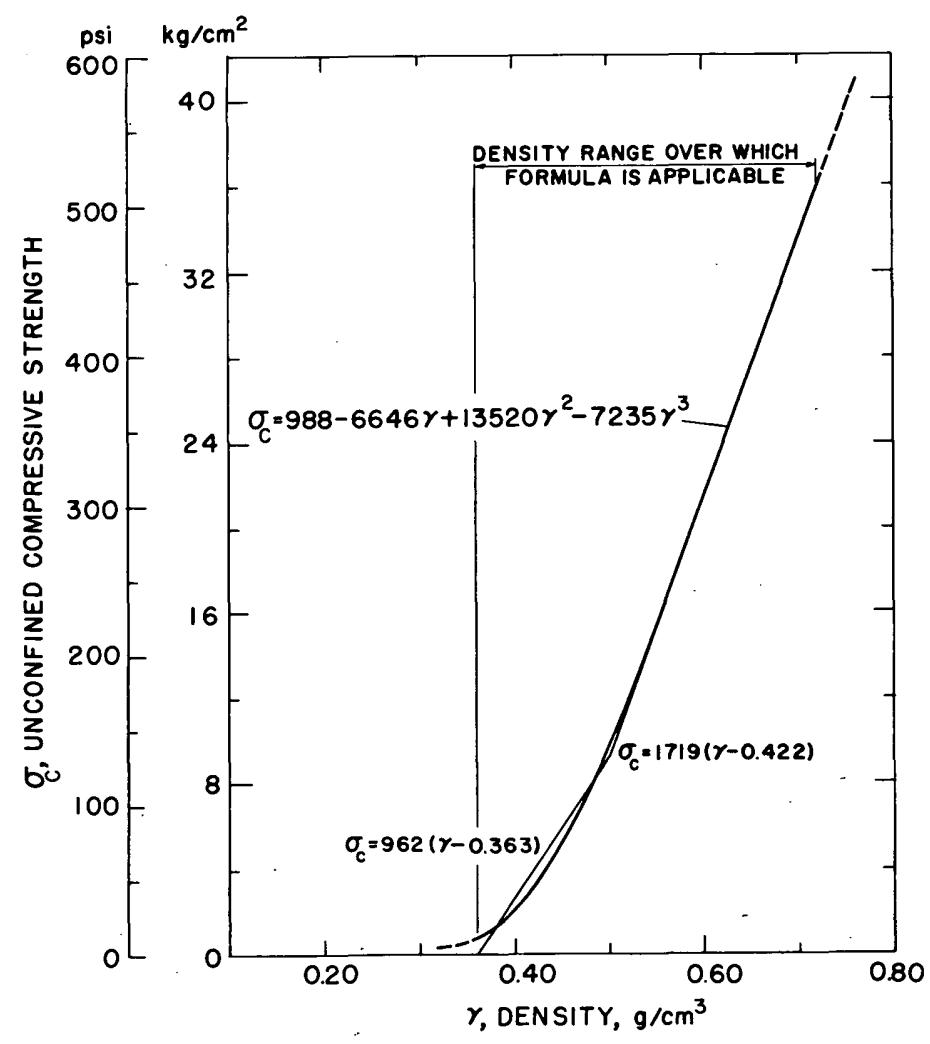

Figure 4. Linear unconfined compressive strength vs density relationships for the combined Butkovich and J. L. Smith data above and below the transition density of $0.50 \mathrm{~g} / \mathrm{cm}^{3}$ in relation to the polynomial relationship for the entire data range. Snow temperature $-10 \mathrm{C}$.

Table II. Statistical data related to polynomial curve in Figure 4.

Symbols

Slopes $\mathrm{m}$, psi $/\left(\mathrm{g} / \mathrm{cm}^{3}\right) \quad B_{1}$

$\mathrm{B}_{2}$

$\mathrm{B}_{3}$

Intercept a, psi

Std error of est $\mathrm{S}_{\mathrm{ye}}$, psi

Multiple corr coef $\mathrm{R}$ !
Butkovich and Smith at $-10 \mathrm{C}, y=0.36$ to $0.72 \mathrm{~g} / \mathrm{cm}^{3}$

$-6.646 \times 10^{3}$

$1.352 \times 10^{4}$

$-7.235 \times 10^{3}$

$9.883 \times 10^{2}$

$3.492 \times 10$

0.953 


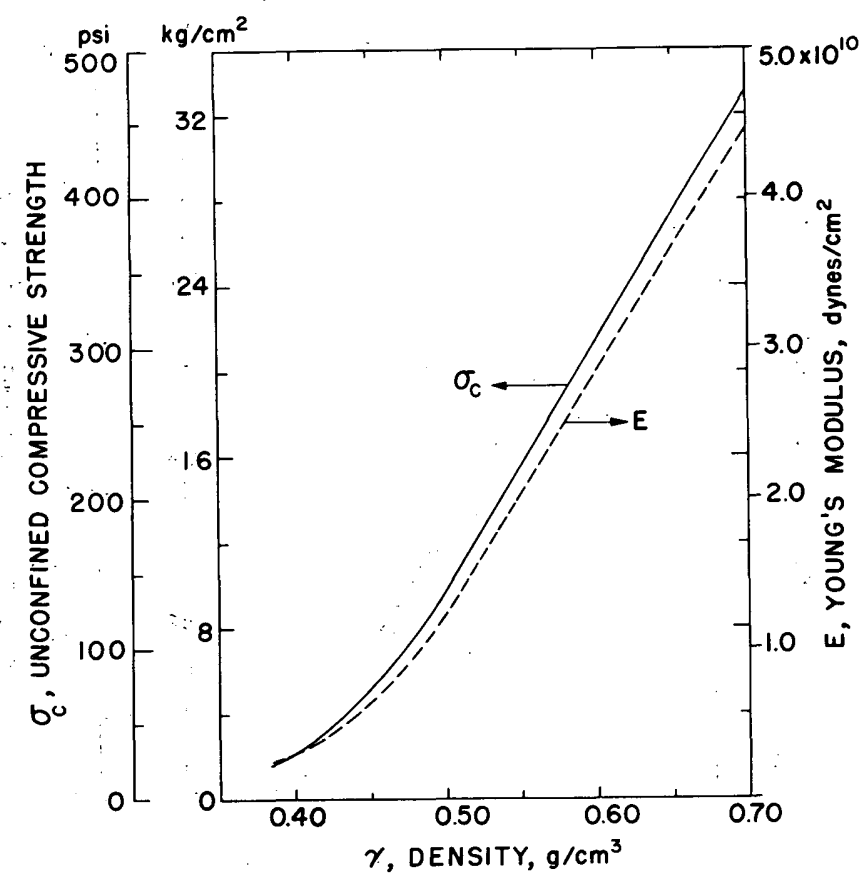

Figure 5. Curve trend comparison between equation 1 l's unconfined compressive strength relationship and J. L. Smith's dynamic Young's modulus vs density relationship. Snow temperature $-10 \mathrm{C}$.

In Figure 5 the curve of equation 11 is shown graphically in relation to J. L. Smith's dynamic Young's modulus vs density curve.* It is readily apparent from this figure that the unconfined compressive strength and dynamic Young's modulus vs density curves do assume similar trends. Finally eq 11 is graphically shown in comparison with the earlier unconfined compressive strength vs density relationships in Figure 6.

If eq 9 is used to determine unconfined compressive strengths above a density of $0.72 \mathrm{~g} / \mathrm{cm}^{3}$, an ultimate strength for snow ice of 850 psi $(59.77$ $\mathrm{kg} / \mathrm{cm}^{2}$ ) is obtained:

$$
\sigma_{c}=1719(\gamma-0.422)=850 \mathrm{psi} \text { when } \gamma=0.917 \mathrm{~g} / \mathrm{cm}^{3} \text {. }
$$

This is $150 \mathrm{psi}\left(10.65 \mathrm{~kg} / \mathrm{cm}^{2}\right)$ more than for clear lake ice at $-10 \mathrm{C}$. The value may nevertheless represent the optimum strength of snow ice $\left(\sigma_{i}\right)$ which is required in the use of eq 3 and 4.

*J. L. Smith's dynamic Young's and shear modulus data are listed.in Table AV of Appendix A. Statistically it was found that a $3 \mathrm{rd}$ degree polynomial regression equation also fitted these data best. See Appendix B for equations and statistical results. Appendix $C$ gives the linear relationships between the unconfined compressive strength of polar snow and its dynamic Young's and shear moduli at $-10 \mathrm{C}$ over the entire $\sigma_{\mathrm{C}}$ range. 


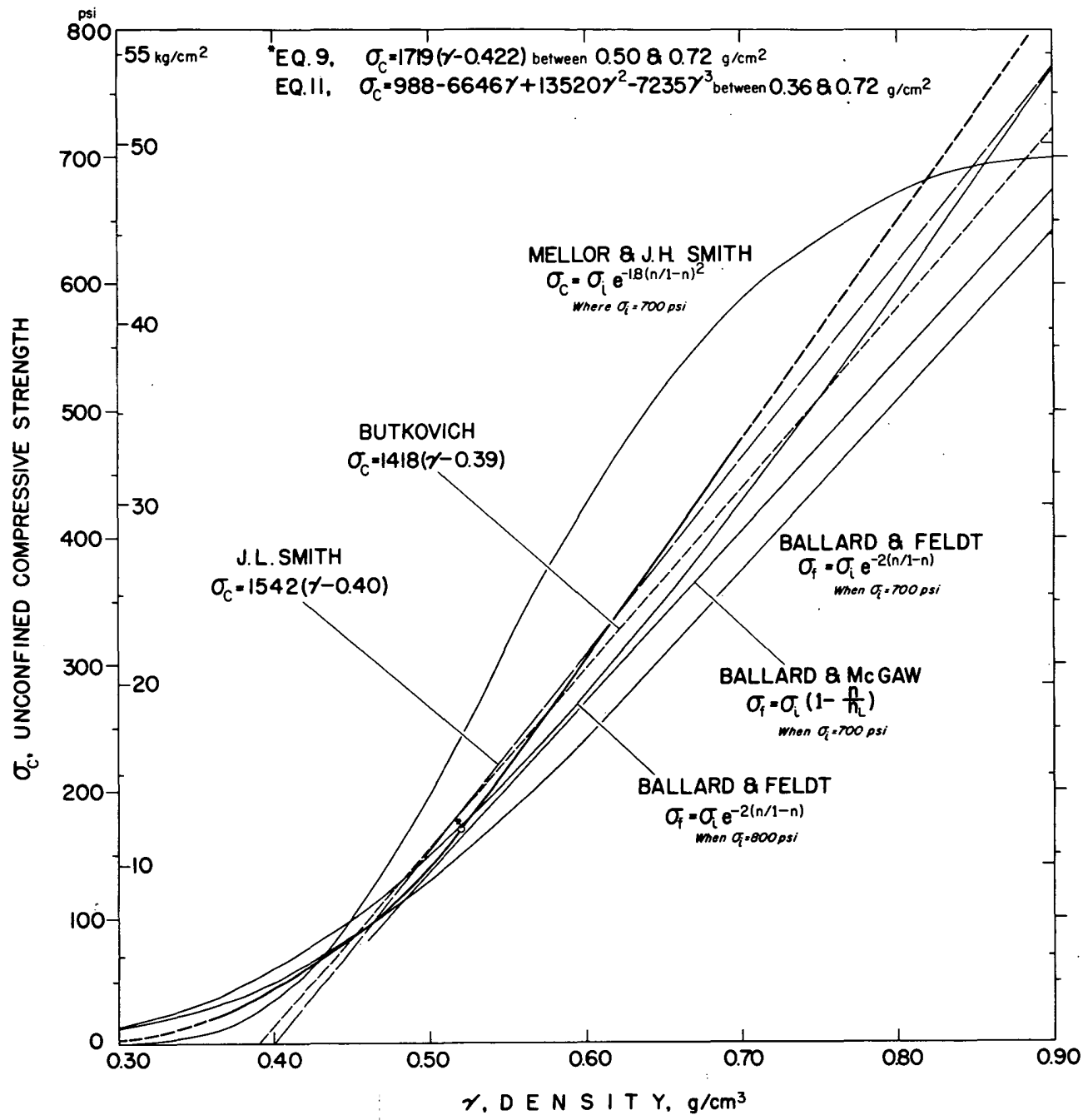

Figure 6. Comparison of the unconfined compressive strength vs density relationship of eq 11 with earlier relationships. Snow temperature $-10 \mathrm{C}$.

Using 850 psi for $\sigma_{i}$ in eq 4 results in the unconfined compressive strength vs density relationship shown in Figure 7 . When this strength vs density relationship is compared with that of the polynomial curve of eq 11 in the same figure, it is apparent that a considerable lack of agreement still exists between the theorized and the empirical expressions in the lowdensity range. 


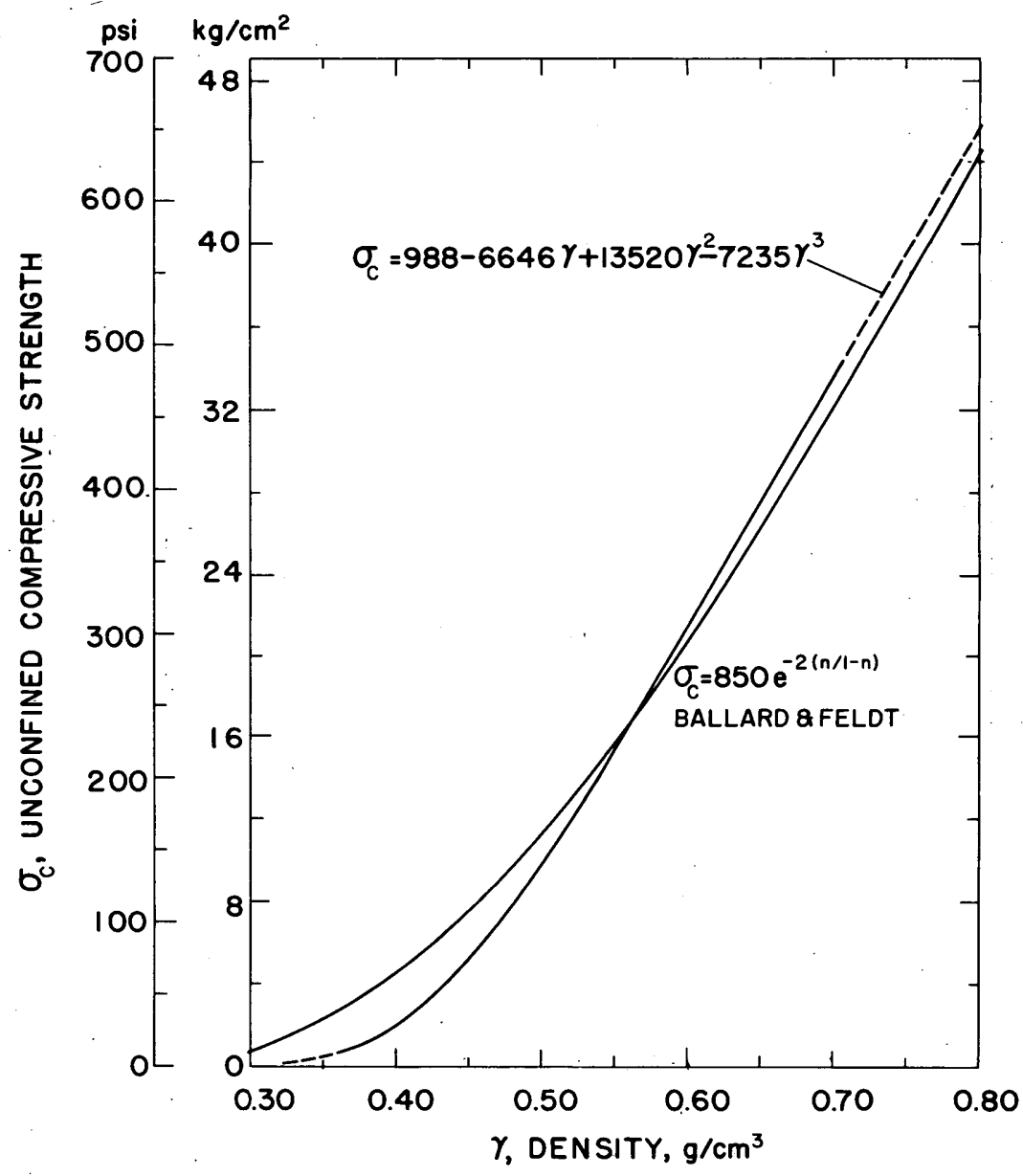

Figure 7. Comparison between the Ballard-Feldt and eq 11 unconfined compressive strength vs density relationships. Snow temperature $-10 \mathrm{C}$.

\section{TEMPERATURE CORRECTION FACTORS}

The Ballard-Feldt, Ballard-McGaw and Mellor-J.H. Smith equations give unconfined compressive strength directly in terms of the associated snow temperature. To relate strength values obtained from the formulas of Butkovich, J. L. Smith, Ballard-McGaw (modified) or the author to a temperature other than $-10 \mathrm{C}$, a temperature correction must be made. Bender (1957) gives an empirical relationship between unconfined compressive strength and temperature:

$$
\log \frac{\sigma_{2}}{\sigma_{1}}=0.16 \log \frac{\theta_{2}}{\theta_{1}}
$$

where:

$$
\begin{aligned}
& \sigma_{1}=\text { unconfined compressive strength at temp } \theta_{1} \\
& \sigma_{2}=\text { unconfined compressive strength at temp } \theta_{2} .
\end{aligned}
$$


Mellor and J.H. Smith also show unconfined compressive strength as a function of temperature. Their equation gives unconfined compressive strength at any temperature as related to - 10C:

$$
\frac{\sigma_{\theta}-\sigma_{0}}{\sigma_{-10}}=1.73 \mathrm{e}^{-4.76 / \theta}
$$

where:

$$
\sigma_{0}=\text { unconfined compressive strength at } \theta=0 \mathrm{C} \text {. }
$$

The curve of the Mellor and J.H. Smith equation was found to be inconsistent with the above equation $\left(\sigma_{0} / \sigma_{-10} \neq 0.41\right.$ as they indicate but is -0.075 when $\left.\sigma_{0}=\sigma_{-10}\right)$. Mellor has, therefore, suggested using the curve (Fig. 8) in preference to the equation.

If polar snows are structurally similar, the straight-line portion of their unconfined compressive strength vs density relationships should, if extended to the abscissa, pass through a "common intercept density." This would be true regardless of temperature and test, provided the test subjected the specimens to similar structural failures, e.g. failure occurring through brittle fracture.

Comparison of the intercept of the extended unconfined compressive strength vs density relationship for vertically sampled South Pole snow with that of eq 9 showed that the two polar snows do indeed share a quasi-common intercept density (Fig. 9). Their intercepts are 0.414 and $0.422 \mathrm{~g} / \mathrm{cm}^{3}$ respectively for a mean of $0.418 \mathrm{~g} / \mathrm{cm}^{3}$. The South Pole samples were broken at $-49.4 \mathrm{C}$, or $39.4 \mathrm{C}$ lower than the samples used to develop eq 9. The difference between the slope of the curve passing through the South Pole $\operatorname{data}\left[2562 \mathrm{psi} /\left(\mathrm{g} / \mathrm{cm}^{3}\right)\right]$ and that of eq $9\left[1719 \mathrm{psi} /\left(\mathrm{g} / \mathrm{cm}^{3}\right)\right]$ is $843 \mathrm{psi} /$ $\left(\mathrm{g} / \mathrm{cm}^{3}\right)$. Dividing the change in the strength slopes by the difference in

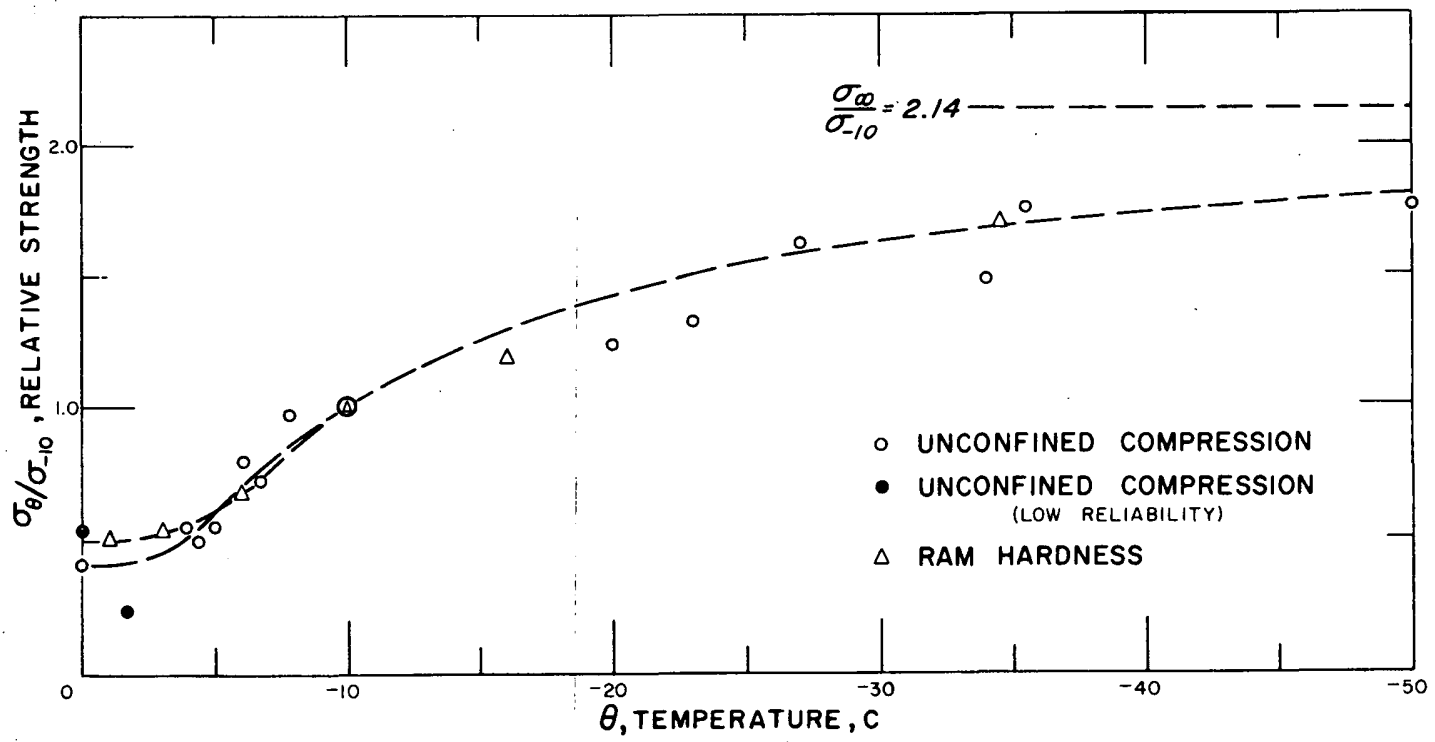

Figure 8. Relative unconfined compressive strength vs temperature (from Mellor-J.H. Smith, 1966). 


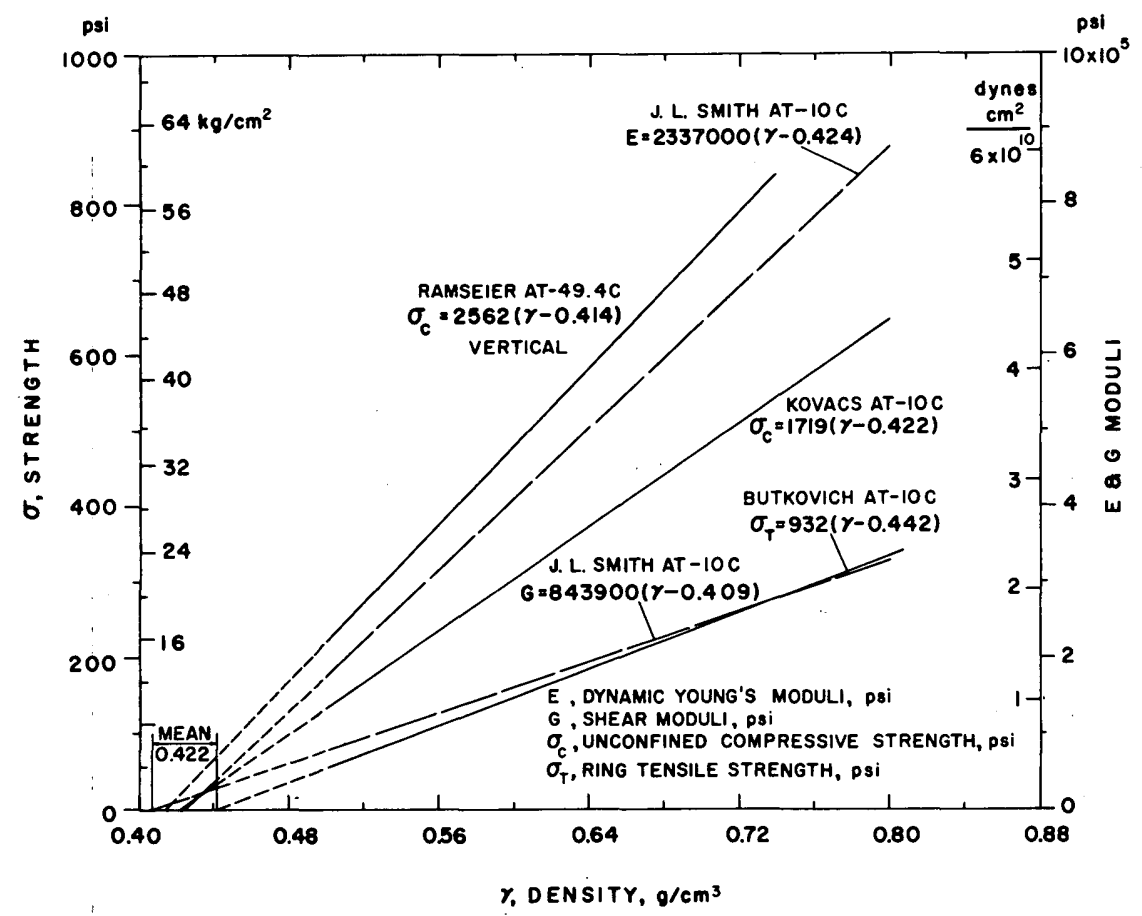

Figure 9. Intercept density relationship between the extended straight-line portions of different tests.

Table III. Statistical data* related to curves in Figure 9.

\begin{tabular}{|c|c|c|c|c|}
\hline Symbols & $\begin{array}{c}\text { Ramseier } \\
\text { unconfined } \\
\text { compressive } \\
\text { strength }\end{array}$ & $\begin{array}{l}\text { Butkovich } \\
\text { ring tensile } \\
\text { strength }\end{array}$ & $\begin{array}{l}\text { J. L } \\
\text { Young's } \\
\text { modulus } \\
\text { (E) }\end{array}$ & $\begin{array}{l}\text { nith } \\
\text { Shear } \\
\text { modulus } \\
(G)\end{array}$ \\
\hline Slope $\mathrm{m}, \mathrm{psi} /\left(\mathrm{g} / \mathrm{cm}^{3}\right)$ & $1.809 \times 10^{2}$ & $9.316 \times 10^{2}$ & $1.612 \times 10$ & 5.824 \\
\hline Intercept a, psi & $-7.489 \times 10$ & $-4.117 \times 10^{2}$ & -6.832 & -2.381 \\
\hline Std error of est $S_{Y e^{\prime}}$ psi & 3.674 & -4.044 & $2.012 \times 10^{-1}$ & $9.063 \times 10^{-2}$ \\
\hline Simple cor $r$ coef $R$ & 0.936 & 0.998 & 0.995 & 0.993 \\
\hline
\end{tabular}

*Test data listed in Appendix A. 
temperature results in a constant for the change in the strength line slope $(M)$ of $\approx 21 \mathrm{psi} /\left(\mathrm{g} / \mathrm{cm}^{3}\right)$ for each dègree $\mathrm{C}$.

Equation 9 can, therefore, be modified to account for unconfined compressive strengths at any temperature below $-10 \mathrm{C}$ as follows:

$\sigma_{c}=(1719+C)(\gamma-0.422)$

where:

$$
\begin{aligned}
& C=\Delta T \times M=\text { change in strength line slope with temperature } \\
& \Delta T=\text { change in temperature below }-10 \mathrm{C} .
\end{aligned}
$$

\section{UNCONFINED COMPRESSIVE STRENGTH OF. POLAR SNOW VS DEPTH-DENSITY AND TEMPERATURE}

From depth-density and temperature profiles taken at Camp Century, the related snow density and temperature per foot were obtained (Table IV). With these data, the unconfined compressive strengths vs depth were calculated using the methods previously discussed. The calculated strengths from the equations of Butkovich (eq 1), Ballard-Feldt (eq 4) and the author (eq 9) were temperature-corrected to the in-situ temperature using the Bender formula (eq 12). For these calculations, $\sigma_{i}$ in eq 4 is 850 psi as extrapolated from eq 9. Strengths calculated using the J. L. Smith equation (eq 2) were temperature-corrected using both the Bender and Mellor-J.H. Smith (eq 13) methods. For comparative purposes, the Ballard-Feldt (eq 4) and Ballard-McGaw (eq 3) equations were used with Butkovich's temperature related strengths of lake ice (Fig. 1) for $\sigma_{i}$. For $n_{L}$ in eq 3 , a value of 0.564 after J.L. Smith was used. A higher $\sigma_{i}$ obtained by extrapolating one of the other $\sigma_{\mathrm{C}}$ equations to a density of $0.917 \mathrm{~g} / \mathrm{cm}^{3}$ was not used in eq 3 for reasons previously discussed. All calculations are listed in Table IV and shown graphically in Figures 10 and 11.

An inspection of the unconfined compressive strength curves in Figure 10 shows that the Ballard-Feldt equation (eq 4) gives the lowest strength values when the temperature related strength of lake ice is used for $\sigma_{i}$. When the same equation is used with the ultimate strength of snow ice extrapolated from eq 9, and temperature-corrected after Bender's formula, $\sigma_{c}$ values comparable to those of the Butkovich equation (eq 2) temperaturecorrected after Bender are obtained. The Ballard-McGaw equation (eq 3) using Butkovich's temperature-related strength of lake ice for $\sigma_{i}$ closely parallels the J. L. Smith (eq 2) values temperature-corrected after Bender (eq 12). By comparing the calculations in Table IV, it is found that the two curves are within a constant $23 \pm 3 \mathrm{psi}\left(1.62 \pm 0.21 \mathrm{~kg} / \mathrm{cm}^{2}\right)$ of one another. When the Bender equation is not used to correct $\sigma_{c}$ strengths formulated by the J.L. Smith equation, the parallelism does not exist. This is apparent in Figure 2 where no temperature correction is necessary at $-10 \mathrm{C}$ and in Figure 10 for the strength curve corrected by the Mellor-J.H. Smith method (eq 13). In addition, as is readily apparent in Figure 10, the high values are again obtained using Mellor's strength equation (eq 5). 
Table IV. Unconfined compressive strength relationships.

\begin{tabular}{|c|c|c|c|c|c|c|c|c|c|c|c|c|}
\hline $\begin{array}{l}\text { Depth } \\
\text { (ft) }\end{array}$ & $\begin{array}{l}\text { Density } \\
\left(\mathrm{g} / \mathrm{cm}^{3}\right)\end{array}$ & $\begin{array}{l}\text { Temp } \\
\left(-{ }^{\circ} \mathrm{C}\right)\end{array}$ & $\begin{array}{l}\text { Balla } \\
\text { (psi) }\end{array}$ & $\begin{array}{c}\mathrm{d}-\mathrm{McGaw} * \\
\left(\mathrm{~kg} / \mathrm{cm}^{2}\right)\end{array}$ & $\begin{array}{l}\text { Balla } \\
\text { (psi) }\end{array}$ & $\begin{array}{l}\mathrm{d}-\text { Feldt } * \\
\left(\mathrm{~kg} / \mathrm{cm}^{2}\right)\end{array}$ & $\begin{array}{l}\text { Balla } \\
\text { (psi) }\end{array}$ & $\begin{array}{c}\mathrm{d}-\text { Feldt } \dagger \\
\left(\mathrm{kg} / \mathrm{cm}^{2}\right)\end{array}$ & $\begin{array}{c}\text { Mellor } \\
\text { (psi) }\end{array}$ & $\begin{array}{l}\text { H. Smith* } \\
\left(\mathrm{kg} / \mathrm{cm}^{2}\right)\end{array}$ & $\begin{array}{c}\text { J. L. } \\
\text { (psi) }\end{array}$ & $\begin{array}{l}\text { Smith } * * \\
\left(\mathrm{~kg} / \mathrm{cm}^{2}\right)\end{array}$ \\
\hline 1 & .520 & 14.0 & 175 & 12. 31 & 161 & 11.32 & 194.5 & 13.7 & 259 & 18.21 & 195 & 13.71 \\
\hline 2 & .520 & 16.8 & 180 & 12.66 & 167 & 11.74 & 200.3 & 14.1 & 269 & 18.92 & 201 & 14.14 \\
\hline 3 & .520 & 17.7 & 183 & 12.87 & 169 & 11.88 & 201.9 & 14.2 & 273 & 19.20 & 203 & 14.28 \\
\hline 4 & .528 & 18.2 & 197 & 13.85 & 180 & 12.66 & 214.0 & 15.0 & 297 & 20.89 & 217 & 15.26 \\
\hline 5 & .535 & 19.0 & 208 & 14.83 & 190 & 13.36 & 225.5 & 15.9 & 317 & 22.29 & 230 & 16.17 \\
\hline 6 & .550 & 19.0 & 233 & 16.38 & 210 & 14.77 & 247.6 & 17.4 & 358 & 25.18 & 257 & 18.07 \\
\hline 7 & .560 & 20.7 & 255 & 17.93 & 228 & 16.03 & 266.4 & 18.7 & 392 & 27.57 & 276 & 19.41 \\
\hline 8 & .558 & 21.2 & 252 & 17.72 & 226 & 15.89 & 264.3 & 18.6 & 390 & 27.43 & 275 & 19.34 \\
\hline 9 & .560 & 21.4 & 257 & 18.07 & 230 & 16.17 & 267.9 & 18.8 & 396 & 27.85 & 278 & 19.55 \\
\hline 10 & .560 & 21.7 & 257 & 18.07 & 231 & 16.24 & 268.4 & 18.9 & 397 & 27.92 & 278 & 19.55 \\
\hline 11 & .558 & 22.0 & 255 & 17.93 & 229 & 16.10 & 265.9 & 18.7 & 394 & 27.71 & 277 & 19.48 \\
\hline 12 & .548 & 22.5 & 240 & 16.88 & 217 & 15.26 & 251.3 & 17.7 & 368 & 25.88 & 260 & 18.28 \\
\hline 13 & .554 & 22.8 & 250 & 17.58 & 225 & 15.82 & 261.1 & 18.4 & 384 & 27.00 & 272 & 19.13 \\
\hline 14 & .564 & 23.0 & 268 & 18.85 & 239 & 16.81 & 277.3 & 19.5 & 414 & 29.11 & 290 & 20.39 \\
\hline 15 & .575 & 23.0 & 287 & 20.18 & 254 & 17.86 & 295.1 & 20.8 & 445 & 31.29 & 309 & 21.73 \\
\hline 16 & .584 & 24.0 & 305 & 21.45 & 271 & 10.06 & 312.1 & 22.0 & 474 & 33.33 & 327 & 23.00 \\
\hline 17 & .598 & 24.0 & 325 & 22.86 & 291 & 20.46 & 336.0 & 23.6 & 507 & 35.79 & 351 & 24.68 \\
\hline 18 & .598 & 24.0 & 325 & 22.86 & 291 & 20.46 & 336.0 & 23.6 & 507 & 35.79 & 351 & 24.68 \\
\hline 19 & .594 & 24.0 & 320 & 22.50 & 287 & 20.18 & 329.1 & 23.1 & 499 & 35.09 & 344 & 24.19 \\
\hline 20 & .590 & 24.1 & 313 & 22.01 & 280 & 19.69 & 322.5 & 22.7 & 488 & 34.32 & 337 & 23.70 \\
\hline 21 & .585 & 24.1 & 306 & 21.52 & 273 & 19.20 & 314.0 & 22.1 & 477 & 33.54 & 328 & 23.07 \\
\hline 22 & .586 & 24.2 & 308 & 21.66 & 275 & 19.33 & 315.9 & 22.2 & 480 & 33.76 & 329 & 23.14 \\
\hline 23 & .590 & 24.2 & 314 & 22.08 & 280 & 19.69 & 322.7 & 22.7 & 492 & 34.60 & 337 & 23.70 \\
\hline 24 & .588 & 24.2 & 311 & 21.87 & 277 & 19.48 & 319.3 & 22.5 & 480 & 33.76 & 334 & 23.49 \\
\hline 25 & .596 & 24.2 & 324 & 22.78 & 290 & 20.39 & 333.0 & 23.4 & 506 & 35.58 & 346 & 24.33 \\
\hline 26 & .599 & 24.2 & 329 & 23.14 & 294 & 20.68 & 338.1 & 23.8 & 511 & 35.94 & 354 & 24.89 \\
\hline 27 & .596 & 24.2 & 324 & 22.78 & 290 & 20.39 & 333.0 & 23.4 & 506 & 35.58 & 346 & 24.33 \\
\hline 28 & .600 & 24.4 & 331 & 23.28 & 296 & 20.82 & 340.0 & 23.9 & 516 & 36.29 & 356 & 25.04 \\
\hline 29 & .607 & 24.4 & 342 & 24.05 & 307 & 21.59 & 352.5 & 24.8 & 532 & 37.41 & 368 & 25.88 \\
\hline 30 & .615 & 24.4 & 356 & 25.03 & 319 & 22.43 & 366.7 & 25.8 & 553 & 38.89 & 382 & 26.86 \\
\hline
\end{tabular}

\begin{tabular}{|c|c|c|c|c|c|c|c|c|c|c|}
\hline $\begin{array}{l}\text { Depth } \\
\text { (ii) }\end{array}$ & $\begin{array}{l}\text { Density } \\
\left(\mathrm{g} / \mathrm{cm}^{3}\right) \\
\end{array}$ & $\begin{array}{l}\text { Temp } \\
\left(--^{\circ} \mathrm{C}\right)\end{array}$ & $\begin{array}{c}\text { J. L. L. } \\
\text { (psi) }\end{array}$ & $\begin{array}{l}\text { Smith } \dagger \dagger \\
\left(\mathrm{kg} / \mathrm{cm}^{2}\right)\end{array}$ & $\begin{array}{r}\text { But } \\
\text { (psi) }\end{array}$ & $\begin{array}{l}\text { vich } \% * \\
\left(\mathrm{~kg} / \mathrm{cm}^{2}\right)\end{array}$ & $\begin{array}{c}\text { Equ } \\
\text { (psi) }\end{array}$ & $\begin{array}{l}\text { tion } 9 \% * \\
\left(\mathrm{~kg} / \mathrm{cm}^{2}\right)\end{array}$ & $\begin{array}{r}E q \\
\text { (psi) }\end{array}$ & $\begin{array}{l}\operatorname{tion} 14 \\
\left(\mathrm{~kg} / \mathrm{cm}^{2}\right)\end{array}$ \\
\hline $\begin{array}{l}1 \\
2 \\
3 \\
4\end{array}$ & $\begin{array}{l}.520 \\
.520 \\
.520 \\
.528\end{array}$ & $\begin{array}{l}14.0 \\
16.8 \\
17.7 \\
18.2\end{array}$ & $\begin{array}{l}226 \\
244 \\
250 \\
268\end{array}$ & $\begin{array}{l}15.89 \\
17.16 \\
17.58 \\
18.85\end{array}$ & $\begin{array}{l}194^{\circ} \\
200 \\
202 \\
216\end{array}$ & $\begin{array}{l}13.64 \\
14.06 \\
14.21 \\
15.19\end{array}$ & $\begin{array}{l}177 \\
182 \\
185 \\
200\end{array}$ & $\begin{array}{l}12.44 \\
12.80 \\
13.08 \\
14.06\end{array}$ & $\begin{array}{l}177 \\
182 \\
184 \\
200\end{array}$ & $\begin{array}{l}12.44 \\
12.80 \\
12.94 \\
14.06\end{array}$ \\
\hline 5 & .535 & 19.0 & 286 & 20.11 & 228 & 16.03 & 215 & 15,12 & 216 & 15.19 \\
\hline 6 & .550 & 19.0 & 319 & 22.43 & 252 & 17.72 & 244 & 17.16 & 244 & 17.16 \\
\hline 7 & .560 & 20.7 & 352 & 24.75 & 270 & 18.99 & 265 & 18.64 & 268 & 18.85 \\
\hline 8 & .558 & 21.2 & 351 & 24.68 & 268 & 18.85 & 265 & 18.64 & 266 & 18.71 \\
\hline 9 & .560 & 21.4 & 357 & 25.11 & 272 & 19.13 & 268 & 18.85 & 270 & 18.99 \\
\hline 10 & .560 & 21.7 & 360 & 25.32 & 273 & 19.20 & 268 & 18.85 & 270 & 18.99 \\
\hline 11 & .558 & 22.0 & 360 & 25.32 & 270 & 18.99 & 265 & 18.64 & 268 & 18.85 \\
\hline 12 & .548 & 22.5 & $340^{\circ}$ & 23.91 & 255 & 17.93 & 248 & 17.44 & 250 & 17.58 \\
\hline 13 & .554 & 22.8 & 356 & 25.04 & 265 & 18.64 & 260 & 18.28 & 262 & 18.42 \\
\hline 14 & .564 & 23.0 & 384 & 27.00 & 282 & 18.42 & 279 & 19.62 & 283 & 19.90 \\
\hline 15 & .575 & 23.0 & 408 & 28.69 & 299 & 21.03 & 301 & 21.17 & 305 & 21.45 \\
\hline 16 & .584 & 24.0 & 437 & 30.73 & 316 & 22.22 & 320 & 22.50 & 326 & 22.93 \\
\hline 17 & .598 & 24.0 & 470 & 33.05 & 339 & 23.84 & 347 & 24.40 & 354 & 24.89 \\
\hline 18 & .598 & 24.0 & 470 & 33.05 & 339 & 23.84 & 347 & 24.40 & 354 & 24.89 \\
\hline 19 & .594 & 24.0 & 460 & 32.35 & 332 & 23.35 & 340 & 23.91 & 346 & 24.33 \\
\hline 20 & .590 & 24.1 & 453 & 31.86 & 327 & 23.00 & 332 & 23.35 & 339 & 23.84 \\
\hline 21 & .585 & 24.1 & 441 & 31.01 & 318 & 22.36 & 323 & 22.71 & 328 & 23.07 \\
\hline 22 & .586 & 24.2 & 443 & 31.15 & 320 & 22.50 & 325 & 22.86 & 331 & 23.28 \\
\hline 23 & .590 & 24.2 & 454 & 31.93 & 327 & 23.00 & 333 & 23.42 & 339 & 23.84 \\
\hline 24 & .588 & 24.2 & 450 & 31.64 & 324 & 22.78 & 330 & 23.21 & 335 & 23.56 \\
\hline 25 & .596 & 24.2 & 468 & 32.91 & 336 & 23.63 & 344 & 24.19 & 351 & 24.68 \\
\hline 26 & .599 & 24.2 & 476 & 33.47 & 341 & 23.98 & 350 & 24.61 & 357 & 25.11 \\
\hline 27 & .596 & 24.2 & 468 & 32.91 & 336 & 23.63 & 344 & 24.19 & 351 & 24.68 \\
\hline 28 & .600 & 24.4 & 480 & 33.76 & 344 & 24.19 & 352 & 24.82 & 360 & 25.32 \\
\hline 29 & .607 & 24.4 & 498 & 35.02 & 356 & 25.04 & 367 & 25.81 & 374 & 26.30 \\
\hline 30 & .615 & 24.4 & 516 & 36.29 & 368 & 25.88 & 383 & 26.93 & 390 & 27.43 \\
\hline
\end{tabular}

$*$ When $\sigma_{i}=$ strength of clear lake ice.

$\dagger$ When $\sigma_{i}=850$ psi (extrapolated from eq 9, then temperature-corrected using Bender's eq 12).

*:* Temperature-corrected after Bender.

$\dagger \dagger$ Temperature-corrected after Mellor and J. L. Smith. 


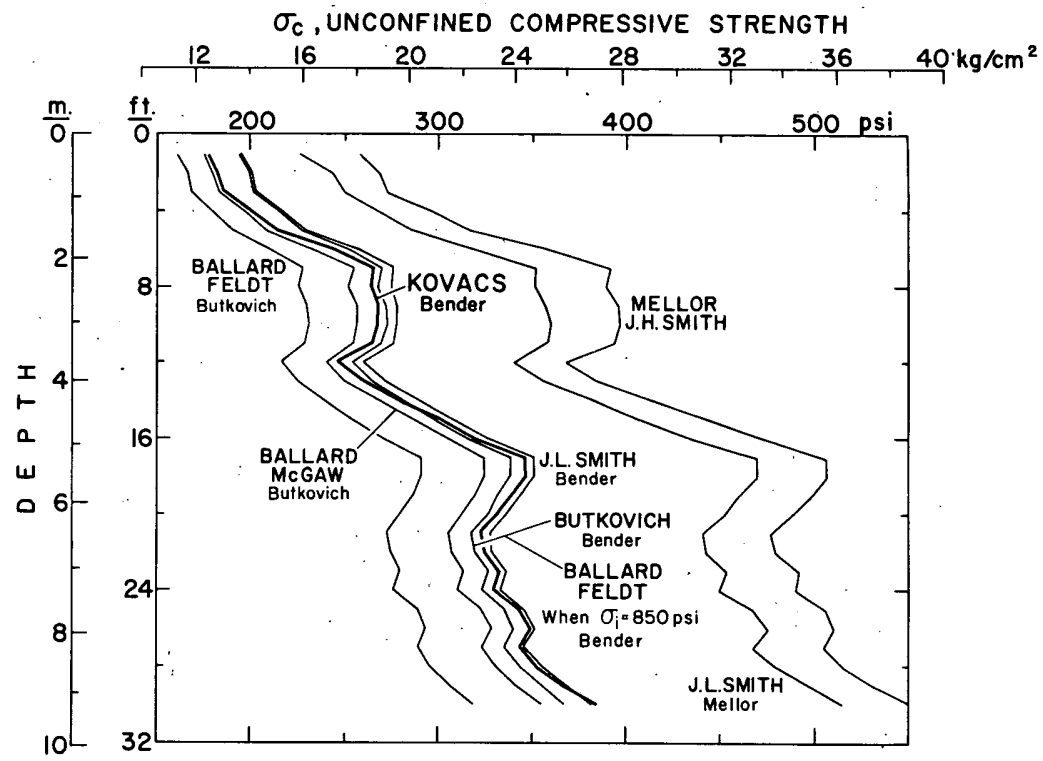

Figure 10. Relationship between values obtained from the different unconfined compressive strength equations when they are used to determine strengths from depthdensity and temperature profiles. The name of the investigator who developed the equation is shown in capital letters; other names indicate type of temperature correction used.

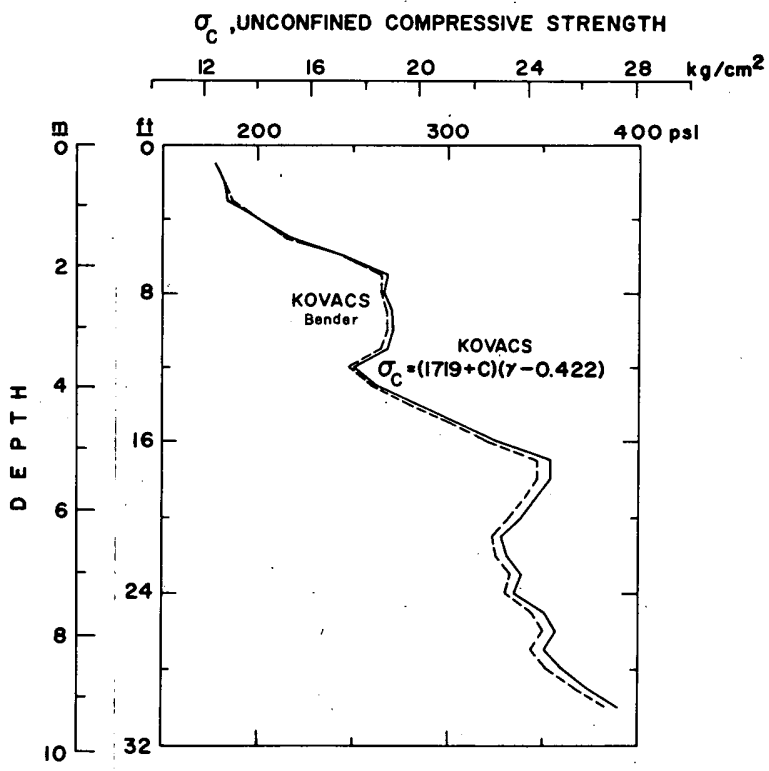

Figure 11. Comparison between the values obtained from eq 9, temperaturecorrected after Bender (eq 12), and from eq 14 when they are used to determine the unconfined compressive strength of polar snow from depth-density and temperature profiles. 
Because of space limitation, $\sigma_{c}$ values obtained using eq 14 are not plotted in Figure 10. They are instead presented in Figure 11 along with eq 9 strength values temperature-corrected after Bender (eq 12). See Kovacs-Bender curve, Figure 10. In Table IV it is seen that at a density of $0.520 \mathrm{~g} / \mathrm{cm}^{3}$ and temperature of $-14 \mathrm{C}$ the two strength curves converge. At a density of $0.615 \mathrm{~g} / \mathrm{cm}^{3}$ and a temperature of $-24.4 \mathrm{C}$ they are $7 \mathrm{psi}$ $\left(0.49 \mathrm{~kg} / \mathrm{cm}^{2}\right)$ apart. This results from the fact that the Bender temperature correction is not a constant but decreases with decreasing temperature. Nevertheless the agreement between the two temperature-corrected $\sigma_{\mathrm{C}}$ values is exceedingly good.

\section{DISCUSSION}

It is not surprising to find empirical unconfined compressive strength vs density relationships in disagreement when one considers that no standard test procedure exists. Mellor-J.H. Smith (1966) and Yosida et al. (1955) have shown the effect of strain rate and temperature upon unconfined strength. Butkovich (1956) points out the effects of end constraint (when the sample diameter-to-length ratio becomes too small) and shape upon crushing strength values. Wuori (1966) mentions the increased strength values and scatter associated with improper press-sample interface surfaces, i.e. using a nonlubricated interface. He also points out the problem of resiliency in the testing machine which permits absorption of energy which is later released rapidly when sample failure is initiated. The applied stress is, therefore, quasi-dynamically applied and the sample fails at a lower stress level than would occur under stable loading conditions. Unless these areas in the unconfined compression test are standardized, better agreement between the results of different investigators will not be possible.

There are strong indications that all polar snows of comparable density are structurally similar (Ramseier, 1963; Gow, 1966). If this is true, the straight-line portion of nondestructive elastic and shear modulus and destructive strength vs density relationships, if extended to the abscissa, should join at a "common intercept density." The strength difference between similar tests would be directly related to temperature. The closely related intercept densities of different tests performed upon South Pole and Greenland snows, shown in Figure 9, tend to support this conclusion. (See Appendix A for associated test data.) With the establishment of standard destructive test procedures which insure sample failure through brittle fracture, test results will become more comparable and the pin pointing of the "common intercept density" related to all polar snows will be possible.

To avoid the possible unfavorable effect of using a temperature correction factor, only strength data obtained at $-10 \mathrm{C}$ were used to develop eq 9 and 11. Although eq 9 represents the unconfined compressive strength of natural snow in the 0.50 to $0.72 \mathrm{~g} / \mathrm{cm}^{3}$ density range of the data, it may accurately express strengths for higher density snow and snow ice. For snow ice above a density of $0.83 \mathrm{~g} / \mathrm{cm}^{3}$ the equation gives $\sigma_{\mathrm{c}}$ strengths higher than tests performed on clear lake ice indicate. Balfard and Feldt (1965) point out that because the resistance along the plane of failure migration in clear lake ice is lower than through snow ice, $\sigma_{c}$ values for snow ice can be expected to be higher than those for clear ice. It therefore seems unrealistic to set the $\sigma_{i}$ strength of clear lake ice as an ultimate for snow ice as Mellor and J.H. Smith do or to use the temperature related $\sigma_{i}$ strength of clear lake ice for that of snow ice in eq 3 and 4 as some inves tigators (Abele et al., 1966; Ramseier, 1966) have done. 
The Mellor-J.H. Smith unconfined compressive strength equation (eq 5) has been shown to give values in considerable disagreement with other empirical relationships. The same is true for their temperature-correction equation ( $\left(\mathrm{eq}^{\prime} 13\right)$. It is beli'eved that this discrepancy is related to the laborator $y$-prepared snow tested and the speed at which the samples in the higher temperature range were broken.

No advantage can be seen in using the Ballard and McGaw equation (eq 3) rather than linear unconfined compressive strength vis density relationships. Equation 3 requires the extrapolation of values from experimental results, which are used simply to express the $\sigma_{c}$ vs density relationship in terms of porosity. The additional computations needed to obtain results directly obtainable from the simpler equation for the same line do not seem justified.

The Ballard and Feldt equation (eq 4) must also use for $\sigma_{i}$ a value extrapolated from an empirical relationship. When eq 4 is compared with eq 11 in Figure 7, it is seen that good agreement exists between the two equations above the "transition density." Below this density eq 4 gives values which are higher than experimental results presently indicate. This is particularly true for snow with a density of less than $0.30 \mathrm{~g} / \mathrm{cm}^{3}$ in which a completely unstable structure exists. It is, therefore, recommended that eq 4 not be used to obtain unconfined compressive strengths below the "transition density" until new test data indicate that such strengths actually exist.

\section{CONCLUSIONS}

Equation 9 as modified to eq 14 is a most simple method for determining the unconfined compressive strength of natural snow at any temperature below $-10 \mathrm{C}$. The equation has been shown to be in good agreement with test results for snow above the "transition density" of $0.50 \mathrm{~g} / \mathrm{cm}^{3}$ and its temperature correction factor has been shown to be in excellent agreement with Bender's (eq 12).

The unconfined compressive strength vs density trend established by eq 11 for 0.36 to $0.72 \mathrm{~g} / \mathrm{cm}^{3}$ density snow has been found to agree with both physical and mechanical properties of polar snow. Because the equation also fits the strength data with a high multiple correlation coefficient of 0.95 and standard error of estimate of 35 , it seems to provide a more realistic unconfined compressive strength vs density relationship for snow in the low density range than the earlier methods discussed.

\section{LITERATURE CITED}

Abele, G.; Ramseier, R. O. ; and Wuori, A.F. (1966) Design criteria for snow runways, The Engineering Journal, The Journal of the Engineering Institute of Canada, vol. 49, no. 5.

Ballard, G.E.H. and Feldt, E. D. (1965) Considerations of the strength of snow, U.S. Army Cold Regions Research and Engineering Laboratory (USA CRREL) Research Report 184.

and McGaw; R.W. (1965) A theory of snow failure, USA CRREL Research Report 137. Also Internat'l Union of Geodesy and Geophysics, Internat'l Symposium on Scientific Aspects of Snow and Ice Avalanches, Davos, Switzerland, April 1965. Pub. no. 69, p. $160-169$. 


\section{LITERATURE CITED (Cont'd)}

Bender, J.A. (1957) Testing of a compacted snow runway, American Society of Civil Engineers, Journal of the Air Transport Division, Paper 1324.

Butkovich, T.R. (1954) Ultimate strength of ice, U.S. Army Snow, Ice and Permafrost Research Establishment (USA SIPRE) Research Paper 11 .

(1956) Strength studies of high-density snow, USA SIPRE Research Report 18.

(1958) Recommended standards for small-scale ice strength tests, USA SIPRE Technical Report 57.

Clark, G. K.C. (1966) Seismic survey northwest Greenland, 1964, USA CRREL Research Report 191.

Fuchs, A. (1959) Some structural properties of Greenland snow, USA SIPRE Research Report 42.

Gow, A.J. (1967) Deep core studies of the accumulation and densification of snow at Byrd Station and Little America, Antarctica, USA CRREL Research Report 197.

Jellinek, H.H.G. (1957) Tensile strength properties of ice adhering to stainless steel, USA SIPRE Research Report 23.

Mellor, M. and Smith, J.H. (1966) Strength studies of snow, USA CRREL Research Report 168.

Mock, S.J. (1966) Multiple and polynomial regression programs for the DDP-24, USA CRREL Technical Note (unpublished).

Nakaya, U. (1959) Viscoelastic properties of snow and ice in the Greenland ice cap, USA SIPRE Research Report 46.

Ramseier, R.O. (1963) Some physical and mechanical properties of polar snow, Journal of Glaciology, vol. 4, no. 36 .

(1966) Role of sintering in snow construction, Journal of Terramechanics, vol. 3, no. 3 .

Smith, J.L. (1965) The elastic constants, strength and density of Greenland snow as determined from measurements of sonic velocity, USA CRREL Technical Report 167.

Wuori, A.F. (1966) Notes on rock mechanics research, USA CRREL Technical Note (unpublished).

Yosida, Z. et al. (1955) Physical studies on deposited snow, Institute of Low Temperature Science, Hokkaido University, Sapporo, Japan. 


\section{APPENDIX A. TEST DATA}

Table AI. Butkovich's unconfined compressive strength data at $-10 \mathrm{C}$.

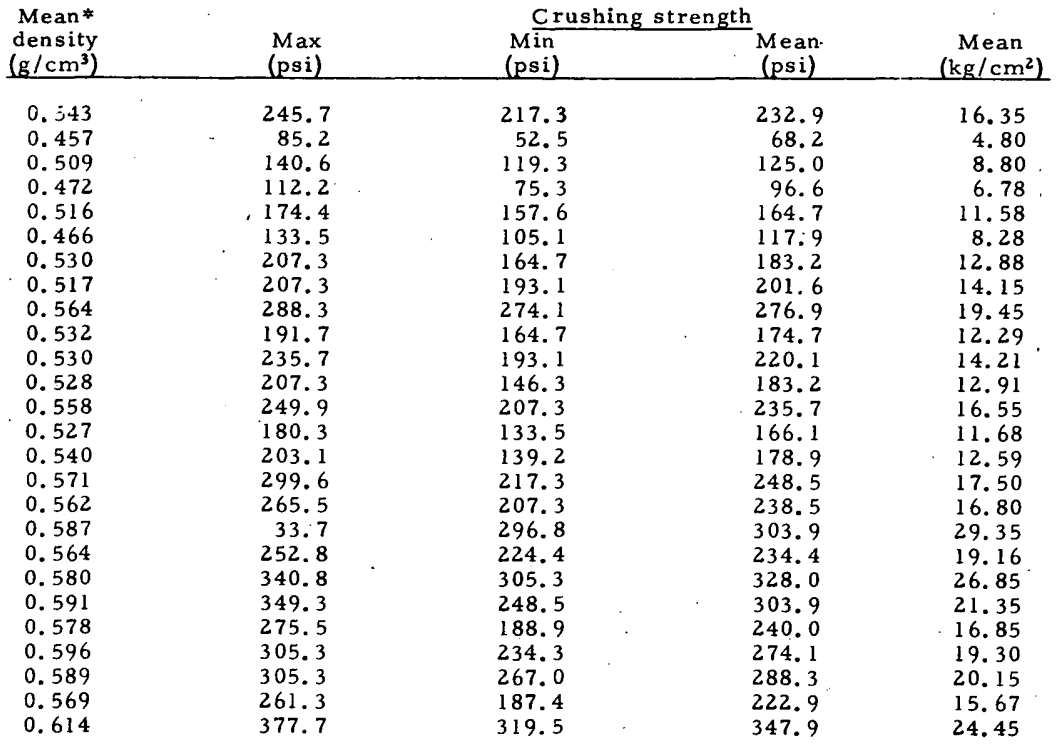

* Mean of six tests.

Table AII. J.L. Smith's unconfined compressive strength data at $-10 \mathrm{C}$.

\begin{tabular}{|c|c|c|c|c|c|c|c|c|}
\hline $\begin{array}{l}\text { Density } \\
\left(\mathrm{g} / \mathrm{cm}^{3}\right)\end{array}$ & $\begin{array}{c}\text { Crushing } \\
\text { (psi) }\end{array}$ & $\underset{(\mathrm{kg}}{\mathrm{str}} \mathrm{cm}_{\left.\mathrm{cm}^{2}\right)}$ & $\begin{array}{l}\text { Density } \\
\left(\mathrm{g} / \mathrm{cm}^{3}\right)\end{array}$ & $\begin{array}{c}\text { Crushing } \\
\text { (psi) }\end{array}$ & $\begin{array}{l}\text { strength } \\
\left(\mathrm{kg} / \mathrm{cm}^{2}\right)\end{array}$ & $\begin{array}{l}\text { Density } \\
\left(\mathrm{g} / \mathrm{cm}^{3}\right)\end{array}$ & $\begin{array}{c}\text { Crushing } \\
\text { (psi) }\end{array}$ & $\begin{array}{l}\text { strength } \\
\left(\mathrm{kg} / \mathrm{cm}^{2}\right)\end{array}$ \\
\hline 0.36 & 22.3 & 1.57 & 0.55 & 227.3 & 15.98 & 0.68 & 329.5 & 23.17 \\
\hline 0.37 & 50.7 & 3.57 & 0.56 . & 200.0 & 14.05 & 0.66 & 508.6 & 35.79 \\
\hline 0.38 & 27.6 & 1.94 & 0.55 & 172.1 & 12.10 & 0.72 & 487.0 & 34.25 \\
\hline 0.40 & 15.2 & 1.05 & 0.56 & 259.7 & 18.25 & 0.68 & 574.7 & 40.41 \\
\hline 0.38 & 7.1 & 0.50 & 0.56 & 165.6 & 13.54 & 0.71 & 551.9 & 38.81 \\
\hline 0.38 & 7.3 & 0.51 & 0.56 & 168.8 & 11.96 & 0.67 & 444.8 & 31.28 \\
\hline 0.40 & 7.1 & 0.50 & 0.64 & 259.7 & 18.25 & 0.66 & 412.3 & 28.99 \\
\hline 0.37 & 11.6 & 0.82 & 0.61 & 313.0 & 22.01 & 0.65 & 451.3 & 31.74 \\
\hline 0.41 & 8.8 & 0.62 & 0.62 & 363.6 & 25.55 & 0.66 & 392.8 & 27.62 \\
\hline 0.37 & 16.7 & 1.17 & 0.63 & 324.7 & 22.83 & 0.69 & 350.6 & 24.66 \\
\hline 0.50 & 144.4 & 10.15 & 0.63 & 445.0 & 31.29 & 0.70 & 409.1 & 28.77 \\
\hline 0.50 & 139.6 & 9.81 & 0.67 & 454.5 & 31.96 & 0.69 & 461.1 & 32.43 \\
\hline 0.49 & 123.4 & 8.40 & 0.67 & 425.3 & 29.91 & 0.68 & 375.0 & 26.37 \\
\hline 0.49 & 139.6 & 9.81 & 0.68 & 386.4 & 27.17 & 0.70 & 370.1 & 26.03 \\
\hline 0.48 & 138.0 & 9.73 & 0.66 & 375.0 & 26.37 & 0.70 & 571.4 & 40.18 \\
\hline 0.49 & 136.4 & 9.60 . & 0.63 & 327.9 & 23.06 & 0.70 & 470.8 & 33.11 \\
\hline 0.50 & 149.3 & 10.50 & 0.64 & 360.4 & 25.34 & 0.68 & 465.9 & 32.76 \\
\hline 0.49 & 123.4 & 8.70 & 0.66 & 405.8 & 28.54 & 0.65 & 405.8 & 28.54 \\
\hline 0.49 & 136.4 & 9.60 & 0.71 & 574.7 & 40.41 & 0.64 & 506.5 & 35.62 \\
\hline 0.48 & 116.9 & 8.24 & 0.68 & 452.9 & 31.85 & 0.68 & 532.5 & 37.45 \\
\hline 0.56 & 246.7 & 17.35 & 0.64 & 347.4 & 24.43 & 0.64 & 227.3 & 15.98 \\
\hline 0.55 & 172.1 & 12.10 & 0.65 & 402.6 & 28.31 & 0.64 . & 373.4 & 26.26 \\
\hline 0.67 & 389.6 & 27.40 & 0.63 & 324.7 & 22.83 & 0.71 & 575.0 & 40.44 \\
\hline 6 & 4 & 19.32 & 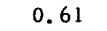 & 76 & 19.4 & & & \\
\hline
\end{tabular}

Table AIII. Butkovich's ring tensile strength at $-10 \mathrm{C}$, Site II.

\begin{tabular}{ccccc}
$\begin{array}{c}\text { Mean* } \\
\text { density } \\
\left(\mathrm{g} / \mathrm{cm}^{3}\right)\end{array}$ & $\begin{array}{c}\text { Max } \\
(\mathrm{psi})\end{array}$ & $\begin{array}{c}\text { Ring tensile strength } \\
\text { Min } \\
(\mathrm{psi})\end{array}$ & $\begin{array}{c}\text { Mean } \\
(\mathrm{psi})\end{array}$ & $\begin{array}{c}\text { Mean } \\
\left(\mathrm{kg} / \mathrm{cm}^{2}\right)\end{array}$ \\
\hline 0.541 & 110.0 & 65.0 & 89.4 & 6.3 \\
0.575 & 145.0 & 99.0 & 124.4 & 8.7 \\
0.613 & 260.0 & 126.0 & 160.2 & 11.3 \\
0.648 & 227.0 & 179.0 & 199.2 & 14.0 \\
0.661 & 272.0 & 149.0 & 201.2 & 14.1 \\
0.681 & 268.0 & 194.0 & 223.0 & 15.7 \\
0.695 & 272.0 & 216.0 & 238.0 & 16.7 \\
0.716 & 292.0 & 210.0 & 250.5 & 17.6
\end{tabular}

\footnotetext{
* Mean of 10 tests.
} 
Table AIV. Ramseier's unconfined compressive strength data* at $-49.4 \mathrm{C}$, South Pole.

\begin{tabular}{|c|c|c|c|c|c|c|c|c|}
\hline $\begin{array}{l}\text { Density } \\
\left(\mathrm{g} / \mathrm{cm}^{3}\right)\end{array}$ & $\begin{array}{l}\text { Crushin } \\
\text { (psi) }\end{array}$ & $\begin{array}{l}\text { strength } \\
\left(\mathrm{kg} / \mathrm{cm}^{2}\right) \\
\end{array}$ & $\begin{array}{l}\text { Density } \\
\left(\mathrm{g} / \mathrm{cm}^{3}\right)\end{array}$ & $\begin{array}{l}\text { Crushing } \\
\text { (psi) }\end{array}$ & $\begin{array}{l}\text { strength } \\
\left(\mathrm{kg} / \mathrm{cm}^{2}\right) \\
\end{array}$ & $\begin{array}{l}\text { Density } \\
\left(\mathrm{g} / \mathrm{cm}^{3}\right)\end{array}$ & $\begin{array}{l}\text { Crushing } \\
\text { (psi) }\end{array}$ & $\begin{array}{l}\text { strength } \\
\left(\mathrm{kg} / \mathrm{cm}^{2}\right)\end{array}$ \\
\hline 0.470 & 120.9 & 8.5 & 0.570 & 420.9 & 29.6 & 0.614 & 612.9 & 43.1 \\
\hline 0.471 & 112.3 & 7.9 & 0.566 & 365.5 & 25.7 & 0.620 & 577.3 & 40.6 \\
\hline 0.474 & 95.3 & 6.7 & 0.571 & 447.9 & 31.5 & 0.616 & 615.7 & 43.3 \\
\hline 0.481 & 119.4 & 8.4 & 0.570 & 479.2 & 33.7 & 0.620 & 496.3 & 34.9 \\
\hline 0.494 & 196.2 & 13.8 & 0.590 & 318.5 & 22.4 & 0.622 & 533.3 & 37.5 \\
\hline 0.498 & 186.3 & 13.1 & 0.587 & 432.3 & 30.4 & 0.627 & 466.4 & 32.8 \\
\hline 0.491 & 174.9 & 12.3 & 0.580 & 487.7 & 34.3 & 0.629 & 594.4 & 41.8 \\
\hline 0.501 & 152.2 & 10.7 & 0.586 & 450.8 & 31.7 & 0.627 & 447.8 & 31.5 \\
\hline 0.508 & 267.6 & 18.8 & 0.586 & 517.6 & 36.4 & 0.630 & 487.7 & 34.3 \\
\hline 0.512 & 278.7 & 19.6 & 0.590 & 470.7 & 33.1 & 0.624 & 516.2 & 36.3 \\
\hline 0.509 & 261.6 & 18.4 & 0.600 & 618.6 & 43.5 & 0.627 & 460.7 & 32.4 \\
\hline 0.517 & 313.5 & 20.6 & 0.592 & 496.3 & 34.9 & 0.628 & 536.1 & 37.7 \\
\hline 0.518 & 268.8 & 18.9 & 0.594 & 428.0 & 30.1 & 0.627 & 543.2 & 38.2 \\
\hline 0.527 & 256.0 & 18.0 & 0.593 & 438.0 & 30.8 & 0.627 & 600.1 & 42.2 \\
\hline 0.522 & 290.1 & 20.4 & 0.603 & 438.0 & 30.8 & 0.631 & 536.1 & 37.7 \\
\hline 0.533 & 317.1 & 22.3 & 0.608 & 540.4 & 38.0 & 0.632 & 571.6 & 40.2 \\
\hline 0.538 & 342.7 & 24.1 & 0.611 & 460.7 & 32.4 & 0.642 & 558.8 & 39.3 \\
\hline 0.540 & 342.7 & 24.1 & 0.607 & 452.2 & 31.8 & 0.640 & 618.6 & 43.5 \\
\hline 0.539 & 354.1 & 24.9 & 0.607 & 445.1 & 31.3 & 0.640 & 506.2 & 35.6 \\
\hline 0.547 & 385.4 & 27.1 & 0.603 & 527.6 & 37.1 & 0.642 & 486.3 & 34.2 \\
\hline 0.547 & 348.4 & 24.5 & 0.612 & 500.5 & 35.2 & 0.646 & 523.3 & 36.8 \\
\hline 0.556 & 351.2 & 24.7 & 0.613 & 453.6 & $31: 9$ & 0.647 & 550.3 & 38.7 \\
\hline 0.557 & 329.9 & 23.2 & 0.609 & 540.4 & 38.0 & 0.647 & $594: 4$ & 41.8 \\
\hline 0.556 & 408.1 & 28.7 & 0.619 & 567.4 & 39.9 & 0.648 & 686.8 & 48.3 \\
\hline 0.556 & 382.5 & 26.9 & 0.618 & 573.1 & 40.3 & 0.646 & 632.8 & 44.5 \\
\hline 0.564 & 479.2 & 33.7 & 0.618 & 577.3 & 40.6 & & & \\
\hline
\end{tabular}

Table Aṽ. J. L. Smith's dynamic Young's and shear moduli at $-10 \mathrm{C}$.

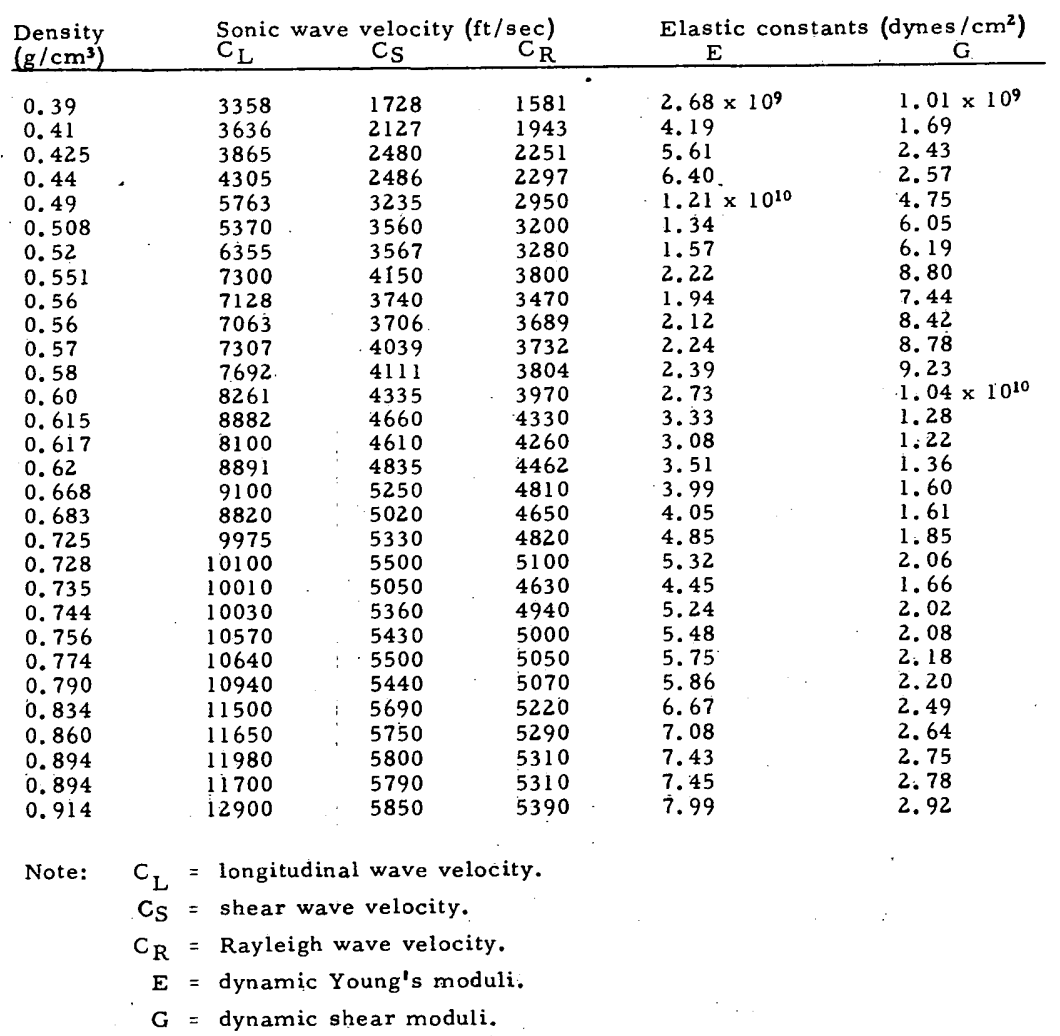


APPENDIX B: STATISTICAL DATA FOR POLYNOMIAL EXPRESSIONS FITTING.J.L. SMITH'S DYNAMIC YOUNG'S AND SHEAR MODULUS DATA

\begin{tabular}{llll} 
Symbols & \multicolumn{2}{c}{ J.L. Smith's } \\
\hline Slopes $\mathrm{m}$, dynes $\mathrm{cm} / \mathrm{g}$ & $\mathrm{B}_{1}$ & $-3.158 \times 10$ & $-1.209 \times 10$ \\
& $\mathrm{~B}_{2}$ & $6.856 \times 10$ & $2.711 \times 10$ \\
& $\mathrm{~B}_{3}$ & $-3.228 \times 10$ & $-1.338 \times 10$ \\
& & 4.038 & 1.481 \\
Intercept a, dynes $/ \mathrm{cm}^{2}$. & $1.943 \times 10^{-1}$ & $8.288 \times 10^{-2}$ \\
Std. error of est. $\mathrm{S}_{\mathrm{y}}$, dynes $/ \mathrm{cm}^{2}$ & 0.997 & 0.996.
\end{tabular}

Polynomials: (for $r=0.390$ to $0.914 \mathrm{~g} / \mathrm{cm}^{3}$ )

$$
\begin{aligned}
& E=4.03-31.58 \gamma+68.56 \gamma^{2}-32.28 \gamma^{3} \\
& G=1.48-12.09 \gamma+27.11 \gamma^{2}-13.38 \gamma^{3}
\end{aligned}
$$


APPENDIX C: RELATIONSHIP BETWEEN THE UNCONFINED COMPRESSIVE STRENGTH OF POLAR SNOW AND ITS DYNAMIC YOUNG'S AND SHEAR MODULI AT - IOC.

Equations:

$$
\begin{aligned}
& \sigma_{c}=0.000738 \mathrm{E}-2.009 \\
& \sigma_{c}=0.001977 \mathrm{G}-10.838
\end{aligned}
$$

Statistical Data Related to the Above Equations

\section{$\underline{\text { Symbols }}$}

Slope $m$

Intercept a, psi

Std. err. of est. $S_{y_{e}}$, psi

Simple corr. coef. R
$\underline{E}$

$7.38 \times 10^{-4}$

$-2.01$

4.496

1.000
$\underline{\mathrm{G}}$

$1.977 \times 10^{-3}$

$-1.08: \times 10$

$1.92 \times 10$

0.998 


\section{DOCUMENT CONTROL DATA - R \& D}

(Security classification of title, body of abstract and indexing annotation must be entered when the overall report is classified) 1. ORIGINA TING ACTIVITY (Corporate author) 2a. REPORT SECURITY CLASSIFICATION

U.S. Army Cold Regions Research and

Engineering Laboratory, Hanover, N.H.

Unclas sified

2b. GROUP

3. REPORT TITLE

DENSITY, TEMPERATURE AND THE UNCONFINED COMPRESSIVE STRENGTH OF POLAR SNOW

4. DESCRIPTIVE NOTES (Type of seport and inclusive dates)

Special Report

5. AU THOR(S) (First name, middlo initial, last namo)

Austin Kovacs

\begin{tabular}{|c|c|c|}
\hline $\begin{array}{l}\text { 6. REPORT DATE } \\
\text { July } 1967\end{array}$ & $\begin{array}{l}\text { 7a. TOTAL NO. OF PAGES } \\
28\end{array}$ & $\begin{array}{c}\text { 7b. NO. OF REFS } \\
19\end{array}$ \\
\hline $\begin{array}{l}\text { 8a. CONTRACT OR GRANT NO. } \\
\text { b. PROJECT NO. }\end{array}$ & $\begin{array}{l}\text { 9a. ORIGিINA TOR'S REPOR. } \\
\text { Special }\end{array}$ & ER(S) \\
\hline $\begin{array}{l}\text { c. DA Task 1 VO25001A130-01 } \\
\text { d. }\end{array}$ & $\begin{array}{l}\text { 9b. OTHER REPORT NO(S) } \\
\text { this roport) }\end{array}$ & hor numbers that may bo asolgned \\
\hline
\end{tabular}

Distribution of this document is unlimited

11: SUPPLEMENTARY NOTES
12. SPONSORING MILITARY ACTIVITY

U.S. Army Cold Regions Research and Engineering Laboratory

\section{ABSTRACT}

The relationships between several empirical and theoretical methods of determining the unconfined compressive strength of polar snow from depthdensity and temperature profiles are discussed and graphically compared. Two unconfined compressive strength equations are proposed for snow at $-10^{\circ} \mathrm{C}$. The formulas take into consideration the decided changes in slope of the Young's and shear modulus curves at a density of $0.5 \mathrm{~g} / \mathrm{cm}^{3}$ for Greenland snow. The slope changes signify that at this density a structural and, therefore, a strength change occur. Analysis of existing test data confirms this reasoning. 
Unclassified

Security Classification

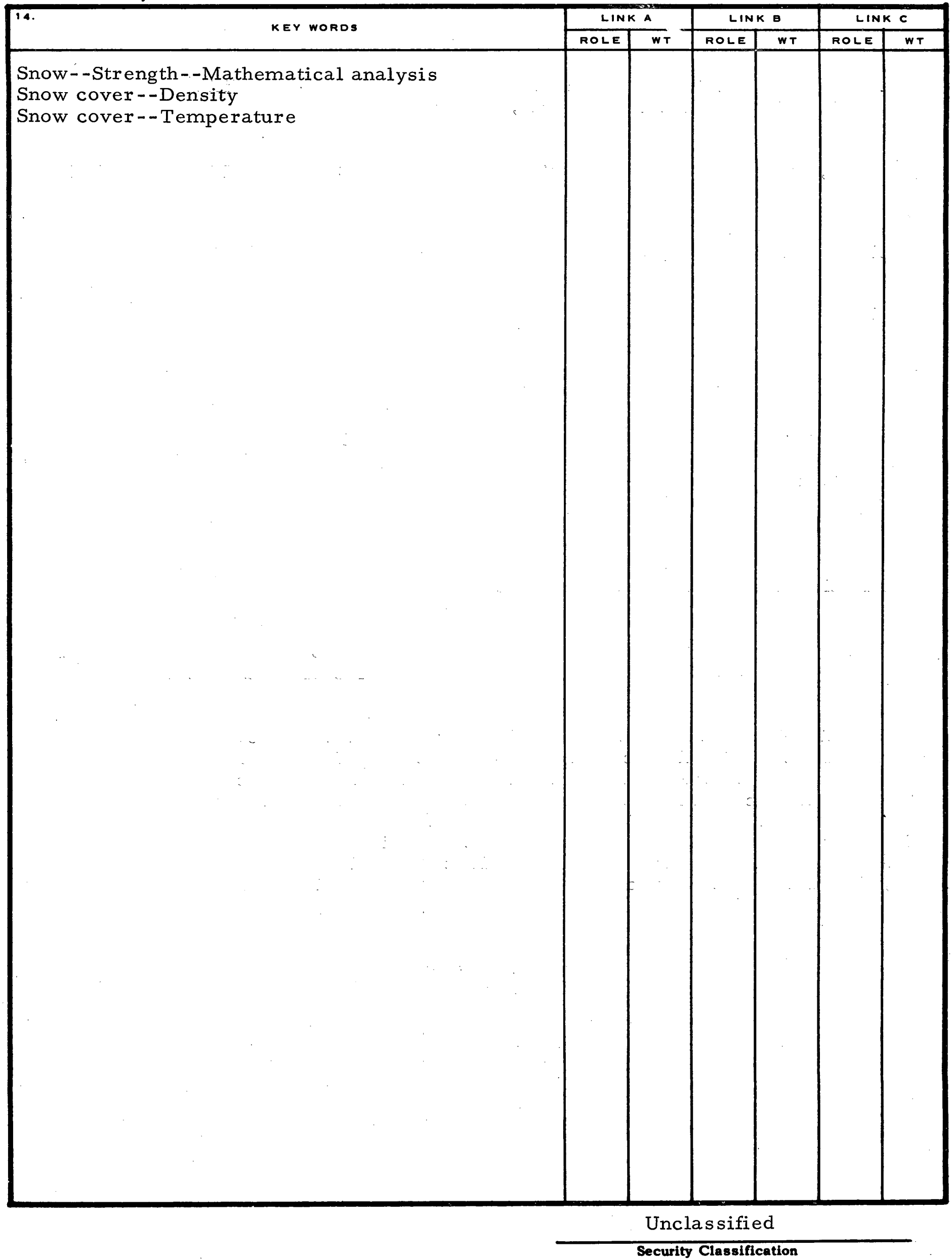

